\title{
Tertiary tectono-metamorphic evolution of the European margin during Alpine collison: example of the Leventina Nappe (Central Alps, Switzerland)
}

\author{
Roger RÜTti $^{1,2}$, Didier Marquer $^{3} \&$ Alan Bruce Thompson $^{1,4}$
}

Key words: Central Alps, Leventina Nappe, deformation history, P-T evolution

\begin{abstract}
The Leventina Nappe represents one of the lowermost exposed units in the Alpine nappe stack and corresponds to a slice of the European margin that was entrained into the Alpine continental accretionary prism during the Tertiary tectonic event. This study yields details regarding the tectonic and metamorphic history of the Leventina Nappe, through detailed analysis of structures and shear zone patterns, and the examination of the Si-content of white mica along a north-south profile. The Leventina Nappe underwent three phases of ductile deformation. Foliation $\mathrm{S} 1$ is mostly sub-parallel to the regionally dominant structural fabric (the $\mathrm{S} 2$ foliation). $\mathrm{S} 2$ foliation is penetratively developed in the structurally higher portions of the Leventina Nappe toward the Simano Nappe, while it is only weakly developed in the core of the Leventina Nappe. A 50 to $200 \mathrm{~m}$ wide mylonite zone, with a D2 top-to-NW sense of shear marks the boundary to the Simano Nappe. Throughout the Leventina Nappe only small-scale D2 shear bands ( $\mathrm{mm}$ to $\mathrm{cm}$ wide) are observed, showing a top-toNW sense of shear. Deformation phase D3 locally generated a vertical axial plane foliation (S3) associated with the large-scale D3 Leventina antiform.

Microtextural evidence and phengite geobarometry were used to constrain the temperature and pressure conditions of equilibration of the Leventina Gneisses. Highest Si (pfu) values are preserved in the core of phengitic micas and reflect pressure and temperature conditions of around $8 \mathrm{kbar}$ at $550{ }^{\circ} \mathrm{C}$ and $10 \mathrm{kbar}$ at $650{ }^{\circ} \mathrm{C}$ in the northern and southern parts of the Leventina Nappe, respectively. Lower $\mathrm{Si}(\mathrm{pfu})$ values from the rims of white micas correspond to a metamorphic pressure of ca. $5 \mathrm{kbar}$ during the exhumation of the unit. These metamorphic conditions are related to the underthrusting of the thinned European margin into the continental accretionary prism during late Eocene time. These new data allow us to propose a kinematic model for the Leventina Nappe during the Tertiary Alpine tectonics.
\end{abstract}

\section{ZUSAMMENFASSUNG}

Die Leventina-Decke stellt eine der tiefsten Einheiten dar, welche im alpinen Deckenstapel aufgeschlossen ist. Sie entspricht einem Teil des europäischen Kontinentalrandes, welcher während der alpinen Kontinentalkollision in den Akkretionskeil einbezogen wurde.

Die detaillierte Analyse der Strukturelemente und der Scherzonenverteilung sowie die Untersuchung von Si-Gehalten in metamorphen Hellglimmern entlang eines Nord-Süd-Profiles ergeben neue Erkenntnisse zur tektonischen und metamorphen Geschichte der Leventina-Decke. Drei Deformationsphasen werden in der Leventina-Decke beobachtet. Die Schieferung S1 ist mehrheitlich sub-parallel zur regional vorherrschenden Schieferung (S2). S2 ist in den höheren Teilen der Leventina-Decke zur Simano-Decke hin penetrativ ausgebildet, wogegen sie im Kern der Leventina-Decke nur schwach ausgeprägt ist. Ein 50 bis $200 \mathrm{~m}$ mächtiger Mylonit-Horizont mit einem NWgerichteten D2-Schersinn stellt im Hangenden die Grenze zur Simano-Decke dar. In der ganzen Leventina-Decke werden nur feine D2-Scherbänder ( $\mathrm{mm}$ bis $\mathrm{cm}$ ) mit einem top-nach-NW Schersinn beobachtet. Die D3-Deformationsphase erzeugte lokal eine vertikale Achsenebenenschieferung S3, welche im Zusammenhang mit der grossmassstäblichen D3-Leventina-Antiform steht.

Mikrotexturen und Phengit-Barometrie wurden benutzt, um Temperaturund Druckbedingungen für die Metamorphose der Leventina Gneise abzuschätzen. Hohe Si (pfu)-Gehalte der Kerne von Hellglimmer widerspiegeln metamorphe Druck- und Temperaturbedingungen von ungefähr 8 kbar bei $550{ }^{\circ} \mathrm{C}$ im Norden und $10 \mathrm{kbar}$ bei $650{ }^{\circ} \mathrm{C}$ im Süden der Leventina-Decke. Tiefere Si (pfu)-Gehalte von Hellglimmer-Rändern entsprechen einem metamorphem Druck von ca. 5 kbar während der Heraushebung der Einheit. Diese metamorphen Bedingungen widerspiegeln das "Underthrusting" der ausgedünnten europäischen Kruste in den kontinentalen Akkretionskeil im späten Eozän. Diese neuen Daten erlauben es uns, ein kinematisches Modell für die tertiäre alpine Orogenese zu formulieren.

\section{Introduction}

The studied area is located in the Central Lepontine Alps, south of the External Crystalline Massifs and north of the Insubric line (see review by Berger et al. 2005 and references therein). This part of the Penninic domain corresponds to the internal part of the Alpine Belt and consists of different tectonic nappes derived, from bottom to top of the nappe stack, of the European

\footnotetext{
${ }^{1}$ Institute for Mineralogy and Petrology, ETH Zurich, Clausiusstrasse 25, 8092 Zurich, Switzerland.

${ }^{2}$ Present address: Dr. M. Kobel \& Partner AG, Büro für Technische Geologie, Grossfeldstrasse 74, 7320 Sargans, Switzerland.

E-mail: roger.ruetti@btgeo.ch

${ }^{3}$ UMR 6249 Chrono-Environnement-Geosciences, Université de Franche-Comté, 16, Route de Gray, 25030 Besançon-Cedex, France.

${ }^{4}$ Also at Faculty of Science, University of Zürich, Zürich, Switzerland.
} 
margin, the Valaisan Basin, the Briançonnais Units and parts of the Liguro-Piedmontais Ocean, respectively (Stampfli et al. 1998; Berger et al. 2005). The Leventina Nappe (Tektonische Karte der Schweiz 1:500000, 2005) is amongst the structurally deepest exposed units in the Central Alps of Switzerland (Fig. 1 and 2). It is part of the lowermost units in the Penninic Nappe stack referred to as Subpenninic units (Milnes 1974; Schmid et al. 2004). This unit therefore is derived from the European margin that was entrained into the Alpine continental accretionary prism. Although the Leventina gneisses have been the subject of a detailed lithologic and petrographic study (Casasopra 1939) and several hypotheses have been formulated regarding their structural position within the Alpine Nappe Stack (e.g. Bossard in Niggli et al. 1936, Berger et al. 2005), its kinematic indicators and pressure-temperature path during the Alpine metamorphic event are barely known and have not been the subject of research in recent times. Note, however, that the relationships of the Leventina Nappe with the northerly adjacent Lucomagno Nappe were not a subject of this study.

To investigate kinematics at a larger scale, shear band patterns (e.g. Gapais et al.1987) are generally very useful and readily interpretable in regionally sheared granitic rocks that were initially homogeneous and isotropic (e.g. Aar Massif: Choukroune \& Gapais 1983; St. Cast granite in Brittany: Gapais et al. 1987; Gotthard Massif: Marquer 1990; Tambo and Suretta Nappes: Marquer 1991; Marquer et al.1996). These shear criteria in ductily deformed crystalline rocks exist at all scales within the crust. Micro- to mesoscale deformation features were investigated to detect and characterize individual shear zones within the Leventina Nappe.

The present study thus aimed at understanding the tectonic processes governing the Leventina Nappe during the Tertiary Alpine event. It uses mapping of the different structures, analysis of shear zone patterns, and investigation of the Si (pfu) content of white micas in gneisses along a north-south profile, to yield details regarding the tectonic and metamorphic history of the Leventina Nappe. These new data will be integrated into a kinematic model for this unit during the Tertiary Alpine tectonics.

\section{Previous Work and Geologic Setting}

The Leventina Nappe represents the structurally deepest of the Subpenninic units in the Central Alps of Switzerland and forms the valley floor and cliffs of Valle Leventina in southern Switzerland (Figs. 1 \& 2). In 1925, Bossard first mapped and described the rocks of the so-called "Tessiner Kulmination". His work was subsequently used in the classic studies by Preiswerk et al. (1934) and Niggli et al. (1936). Bossard (1925) already postulated that the Leventina Gneisses form an independent nappe - contrary to many geologists working in the area at that period (see various tectonic schemes in Niggli et al. 1936; Berger et al. 2005). This metagranitic body of unspectacular and homogeneous appearance was later thoroughly mapped and described by Casasopra (1939). After these pioneering studies little re- search has been conducted in this unit, probably due to the homogeneous character of the unit. The Leventina Gneisses are important from a geotechnical point of view as they support the Gotthard highway and some $20 \mathrm{~km}$ of the new railroad tunnel (Gotthard Base Tunnel GBT of the "Neue Eisenbahn-AlpenTransversale" NEAT) currently in construction.

The Leventina Gneisses consist of a Variscan metagranite with trondhjemitic-leucogranitic chemical bulk composition, with some scarce lenses of different composition such as paragneiss, micaschist and amphibolite (Casasopra 1939). These lenses, which represent remnants of the country rocks of the Leventina metagranites at the time of its magmatic intrusion, are now completely integrated into the Leventina Gneisses (Hiss 1975). In the north of the unit, the Leventina Gneisses contain the so-called "Intercalazione Centrale di Chironico - Faido - Piottino" (Casasopra 1939). This 80 m wide zone consists of various rock types such as quartzite, micaschist, paragneiss, aplite and amphibolite. The Leventina Gneisses have intrusion ages of ca. $270 \mathrm{Ma}$, as indicated by their zircon age pattern (Allègre et al. 1974; Köppel et al. 1980; Köppel 1993).

The Leventina Nappe is separated from the Simano Nappe by metasediments of presumed but unproven Mesozoic age (Niggli et al. 1936; Bianconi 1971; see Figs. 1 \& 2). According to some studies, the Lucomagno unit is interpreted as the metasedimentary country rock into which the magmatic protoliths of the Leventina Gneisses intruded and accordingly Leventina Gneisses and Lucomagno metasediments are viewed as two lithologies of a coherent Alpine Nappe referred to as the Lucomagno-Leventina Nappe (Fig. 1; Milnes 1976; Spicher 1980; Etter 1992). Based on the existence of nappe-dividing Mesozoic metasediments, the Lucomagno (Bianconi 1971) and Leventina Nappes are locally separated by Mesozoic metasediments, and can actually be divided into two distinct nappes north of the area of this study (Berger et al. 2005; Rütti et al. 2005).

Toward the south, the metasediments found between Leventina and the overlying Simano Nappe are rare and the boundary has been defined by lithological criteria. This boundary is formed by a strongly deformed mylonitic horizon already described by Casasopra (1939) and confirmed by several other studies (Irouschek 1983; Merle et al. 1989; Timar-Geng et al. 2004; Rütti et al. 2005). Whether the lower boundary of the Leventina Nappe is represented by an anhydrite-bearing zone known from the subsurface (Biaschina Bore Hole) remains an open question, as below the anhydrite-bearing zone Leventina Gneisses are found again (Hiss 1975). Recently, Timar-Geng et al. (2004) used samples from the Leventina Gneisses to constrain the latest exhumation stage of this unit by Apatite Fission Track ages dated around 10 to $3.7 \mathrm{Ma}$.

\section{Tertiary Deformation and Kinematics}

\subsection{Deformation History}

Although the Leventina Gneisses have not previously been the subject of a detailed structural study, there are data regarding 


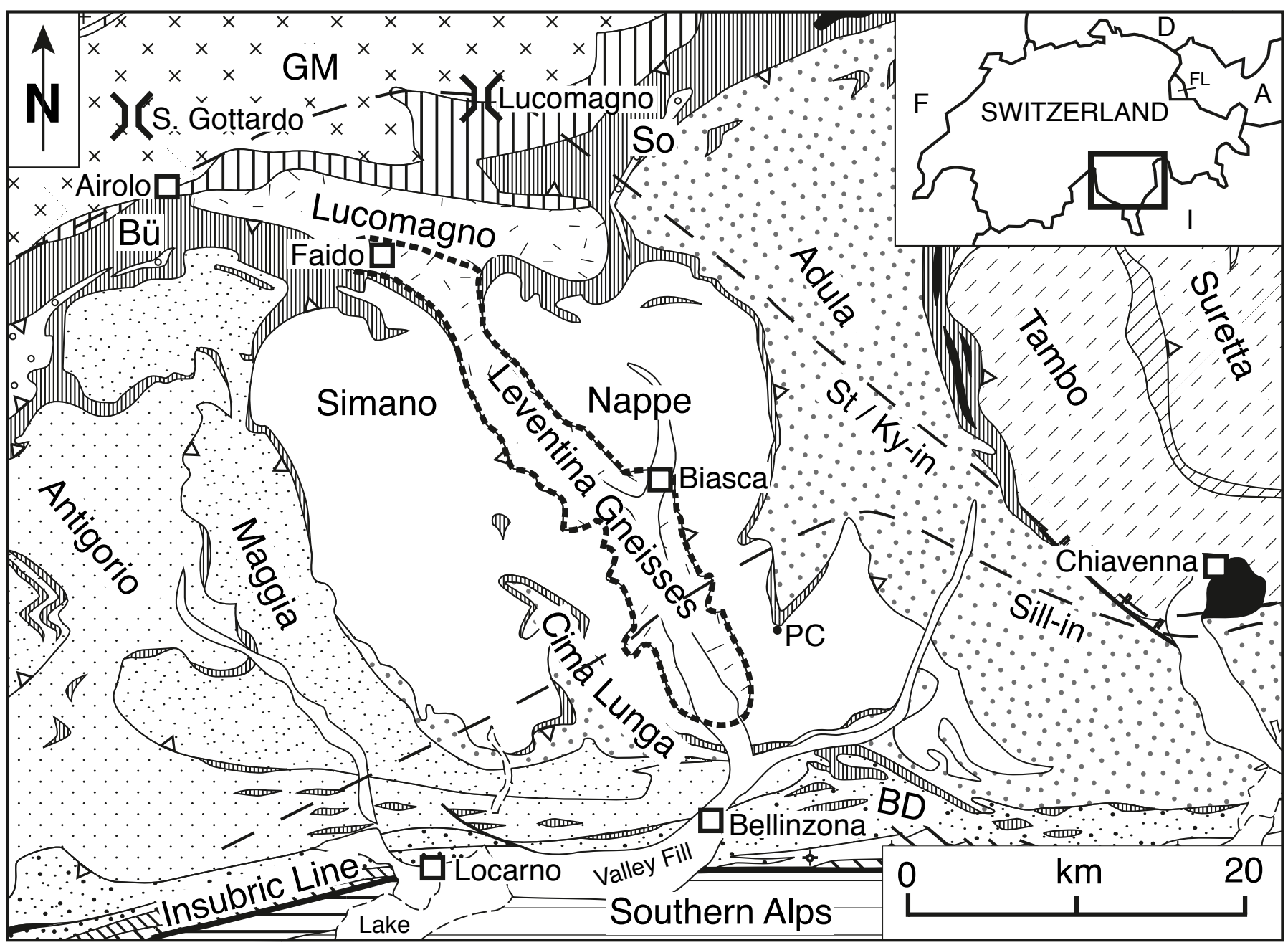

Fig. 1. Map of the Central Alps of Switzerland modified from Spycher (1980). The study area is enclosed by the dashed line. The staurolite/kyanite-in and silimanite-in isograds are from Niggli and Niggli (1965) and Thompson (1976). Abbreviations: BD = Bellinzona-Dascio Zone, GM = Gotthard Massif, So = Soja Zone, $\mathrm{Bü}=$ Bündnerschiefer, $\mathrm{PC}=$ Pizzo di Claro.

the orientation of the main foliation outlining the contours of the Toce and Ticino culminations (Wenk 1955). Structural data were also compiled by Merle et al. (1989) and more recently Maxelon \& Mancktelow (2005). During our study, structural data were collected in order to define the internal structure of the Leventina Nappe and the structural relationships with the surrounding units.

\section{Deformation Phase D1}

In much of the Leventina Gneisses, S1 is sub-parallel to the regionally dominant gently NW-dipping S2 foliation and in many outcrops it is not possible to distinguish between these two foliations since both are associated with north-directed shearing (Rütti et al. 2005 and references therein). However, the relation- ships between the S1 and the S2 foliations are well preserved in the frontal part of the Leventina Nappe. For example, in the Dazio Grande Gorge (Swiss Coordinates* 700883/149665), the S1 foliation of the Leventina Gneisses is affected by the subsequent deformation phase D2 (Fig. 3a). In this place, the S1 foliation is partly preserved between anastomosing D2 shear zones.

\section{Deformation Phase D2}

The main foliation S2 is axial planar to mesoscopic folds affecting S1, and is more or less penetrative throughout the entire unit. Towards the core of the nappe, the main foliation S2 becomes less penetrative as some of the large alkali feldspar augen are not aligned along S2, but show a more random distribution. Also white micas and biotites in these rocks are less

*Throughout this paper references to Swiss map Coordinates are made with the letters S.C. 


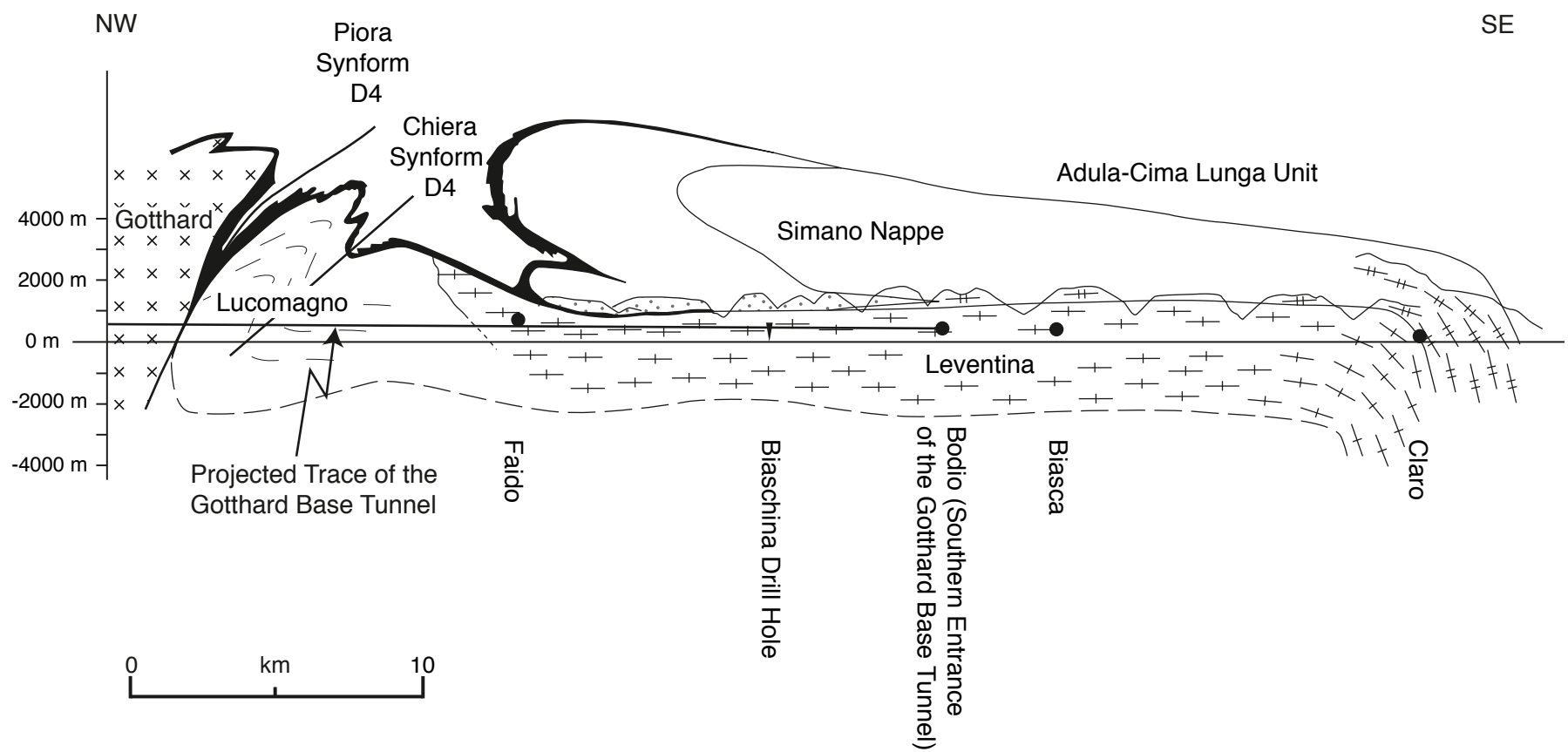

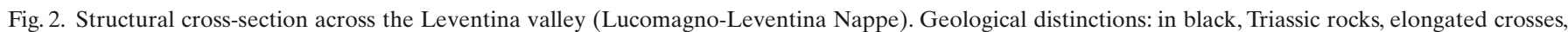

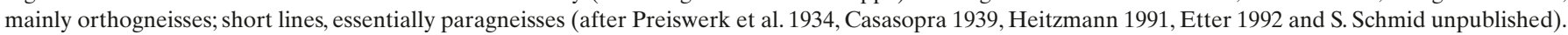
The dashed line represents a suggested tectonic contact with a deeper non-exposed unit at the base of the Leventina Nappe.

rigorously oriented along S2. Close to the overlying Simano Nappe, a 50 to $200 \mathrm{~m}$ wide mylonitic horizon (Fig. 3b) is observed. This mylonite crops out along both the eastern and western side of Valle Leventina. The protolith of the mylonite, as determined from the mineral assemblage and modal estimations, corresponds to the Leventina Gneisses. In some cases a strongly sheared leucocratic rock containing quartz, alkali feldspar, plagioclase, biotite and muscovite (e.g. a leucogranite) is associated with the mylonite and can macroscopically be mistaken for quartzite. Asymmetric feldspar porphyroclasts as well as shear bands indicate a top-to-NW sense of shear (Fig. 3b), which is assigned to the D2 deformation. Figure 4 shows a map of the trend of the main foliation S2. The field measurements were averaged in order to produce a better legible map. The overall flat-lying D2 foliation shows orientation deflections and inceasing angles of dip near the boundaries of the mapped area, due to the superimposition of D3 and D4 deformations described below.

\section{Deformation Phase D3}

During D3, large-scale regional folds with small amplitudewavelength ratios (1 to $2 \mathrm{~km}$ amplitude, wavelength 8 to $10 \mathrm{~km}$ ) affected the whole nappe stack in this internal part of the Alps. The Leventina Antiform is one of these large-scale N-S oriented folds and observed near or at the eastern boundary between Leventina Nappe and overlying Simano Nappe (Fig. 4). East of its fold axial trace, S2 dips east. In the Dazio Grande gorge-outcrop (S.C. 700883/149665), the overprinting relationships between $\mathrm{N}-\mathrm{S}$ oriented D3 folds and the S2 foliation are observed at the large scale (20 to 30 meters). A gentle undulation (amplitude of 6 to 8 meters) also affects all the structures observed in the gorge.

Table 1 correlates structures and deformation phases of the Leventina Nappe with those of the Simano Nappe in the hanging wall to the east and the west according to the relative age of deformation, as well as the metamorphic conditions deduced by several studies in the Simano Nappe. Table 1 shows that the deformation history of the two units is very similar. However, the directional kinematics during a same deformation phases differ when going east and structurally upwards in the Alpine Nappe pile as will be discussed in the next section.

Following D3 deformation, all the structures are steepened in the northern part of the Leventina Nappe by the D4-Chiera synform (see Fig. 2; Milnes 1974; Etter 1992), related to backfolding induced by Oligo-Miocene backthrusting of the Gotthard and Aar massifs (Marquer 1990). Toward the south the main foliation S2 is also strongly steepened due to the formation of the Southern Steep Belt associated with Oligocene dextral and reverse displacement along the Insubric Line (Milnes 1974).

\subsection{Kinematic History}

The distribution of shear band patterns was studied in numerous quarries of Valle Leventina. The quarries represent the bulk of the accessible 3D-outcrops of the Leventina Gneisses on the valley floor. Shear bands within the Leventina Gneisses were generally found to be small, the bands being a few $\mathrm{cm}$ wide (Figs. 3c \& 3d). They are associated with and deflect the

S160 R. Rütti et al. 

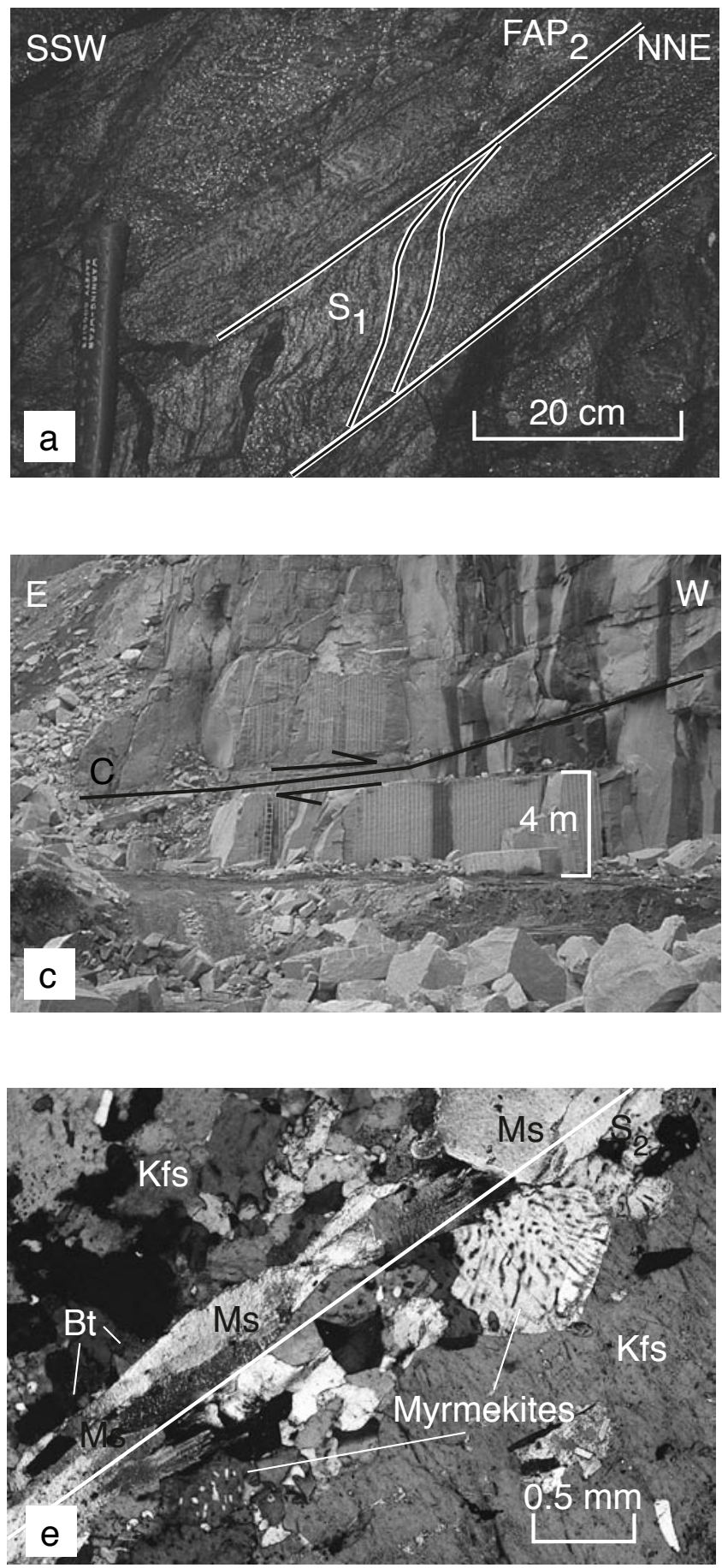

composite S1-S2 foliation. The C-type shear bands (Passchier \& Trouw, 1996) therefore formed during D2 deformation (Fig. 3d). The shear bands dip toward the NW and the shear sense is consistently top-to-NW (Fig. 3d). Figure 5 shows plots of the main foliation S2, the associated stretching lineation L2, and the orientation of shear bands measured in the Leventina Gneisses. The main foliation is mainly horizontal throughout the unit. L2 stretching lineations (Ls) consistently strike NW-
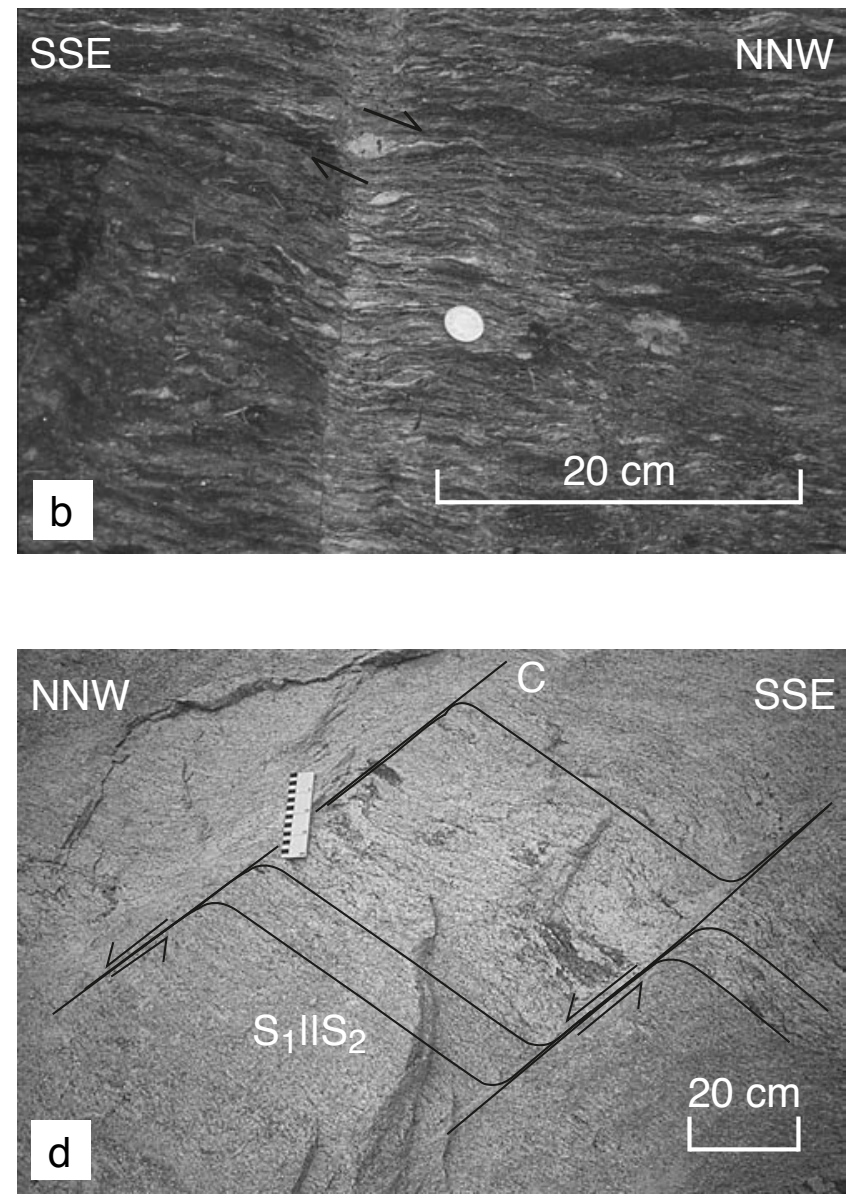

Fig. 3. Field pictures and microphotographs of structural features observed in the Leventina Gneisses. a) D1/D2 interference in the Leventina Gneisses in the Dazio Grande gorge (S.C. 700883/149665). b) Asymmetric feldspar clast showing top-to-NW sense of shear near Faido (S.C. 705520/147010). c) cm-wide shear bands in a quarry near Iragna (S.C. 718290/130120). d) $\mathrm{cm}$-wide shear zone in the Leventina Gneisses showing top-to-NW sense of shear (S.C. 718200/129925). e) Myrmekite-structures present at the rim of plagioclase grain exposed to the principal strain axis $\mathrm{Z}$ as described by Simpson (1985) and Simpson \& Wintsch (1989) (Sample LEV012, S.C. 710250/138975).

SE, which accords well with observations in the overlying units (see Rütti et al. 2005 for data on the Simano Nappe,). Shear bands (C planes) have the same strike as S2 planes but show higher angles of dip toward the NW. The stretching lineation (Lc) associated with the shear bands is also oriented in a NWSE direction, except for the measurement in Cresciano (Fig. 5). The geometrical relationships between the shear planes and the schistosity reveal a bulk top-to-NW sense of shear (Fig. 5). 
Table 1. Correlation of Mesoscopic structural elements in the Subpenninic Domain of the Central Alps of Switzerland (Leventina Nappe and Simano Nappe) and inferred ages after Becker (1993), Gebauer (1996), Hurford et al. (1989), Nievergelt et al. (1996), Villa \& von Blanckenburg (1991) von Blanckenburg (1992) and the references cited in the Table.

\begin{tabular}{|c|c|c|c|}
\hline \multicolumn{4}{|c|}{ Correlation of structural elements in outcrop } \\
\hline Age/Nappe & western Simano Nappe & Leventina Nappe & eastern Simano Nappe \\
\hline & $\begin{array}{l}\text { Grond et al. (1995); } \\
\text { Pfiffner (1999); } \\
\text { Rütti et al. (2005). }\end{array}$ & This study & $\begin{array}{l}\text { Partzsch (1998); } \\
\text { Rütti (2001); } \\
\text { Nagel et al. (2002). }\end{array}$ \\
\hline $\begin{array}{l}\text { Eocene to } \\
\text { Oligocene } \\
\text { (40 to } 35 \text { Ma) }\end{array}$ & $\begin{array}{l}D_{1}(\text { Nappe formation): } \\
\text { Subhorizontal } \mathrm{S}_{1}, \mathrm{NW}-\mathrm{SE} \text {-oriented } \mathrm{L}_{1} \text {, } \\
\text { top-to-NW thrusting, } \\
\text { isoclinal folds (relict, rare). } \\
\mathrm{T}: \sim 500^{\circ} \mathrm{C} ; \mathrm{P}: 9 \text { to } 11 \text { kbar. }\end{array}$ & $\begin{array}{l}D_{1} \text { (Nappe formation): } \\
\text { Subhorizontal } \mathrm{S}_{1} \text {, except in the north } \\
\text { toward the NSB, NW-SE oriented } \mathrm{L}_{1} \text {, } \\
\text { top-to-NW-thrusting. } \\
\text { T: }>550^{\circ} \mathrm{C} ; \mathrm{P}: 8 \text { to } 10 \text { kbar. }\end{array}$ & $\begin{array}{l}D_{1}(\text { Zapport phase): } \\
\text { Foliation } \mathrm{S}_{1}, \mathrm{~N}-\mathrm{NNE} \text {-dipping } \mathrm{L}_{1} \text {, } \\
\text { top-to-N shear sense, } \\
\text { isoclinal, similar folds. } \\
\mathrm{T}:>600{ }^{\circ} \mathrm{C} ; \mathrm{P}: \sim 12 \mathrm{kbar} \text {. }\end{array}$ \\
\hline $\begin{array}{l}\text { Oligocene } \\
\text { (pre-Bergell, } \\
35 \text { to } 30 \mathrm{Ma} \text { ) }\end{array}$ & $\begin{array}{l}D_{2} \text { (Nappe folding): } \\
\text { subhorizontal "main" foliation } \mathrm{S}_{2}, \mathrm{NW}-\mathrm{SE}- \\
\text { dipping } \mathrm{L}_{2} \text { with top-to-NW in lower, and } \\
\text { top-to-SE shear sense of in upper parts. } \\
\text { T: } \sim 650^{\circ} \mathrm{C} ; \mathrm{P}: 8 \text { to } 10 \mathrm{kbar} \text {. }\end{array}$ & $\begin{array}{l}D_{2} \text { (Nappe folding): } \\
\text { subhorizontal "main" foliation } \mathrm{S}_{2}, \mathrm{NW}- \\
\text { SE-dipping lineation } \mathrm{L}_{2} \text {, top-to-NW- } \\
\text { sense of shear in the upper parts. } \\
\text { T: } \sim 550 \text { to } 650^{\circ} \mathrm{C} ; \mathrm{P}: 8 \text { to } 10 \mathrm{kbar} \text {. }\end{array}$ & $\begin{array}{l}\mathrm{D}_{2} \text { (Niemet-Beverin phase): } \\
\text { New axial planar foliation } \mathrm{S}_{2} \text {, stretching } \\
\text { lineation } \mathrm{L}_{2} \text {, top-to-SE shear sense, } \\
\text { open to tight isoclinal folds, } \\
\text { T: } 650 \text { to } 700^{\circ} \mathrm{C} ; \mathrm{P}: 10 \text { to } 12 \mathrm{kbar} \text {. }\end{array}$ \\
\hline $\begin{array}{l}\text { Miocene to } \\
\text { today }\end{array}$ & & $\begin{array}{l}\text { post } D_{3} \text { : } \\
\text { Ultracataclasites and pseudotachylytes } \\
\text { in the upper part, kinking of } \\
\text { the "main" foliation }\end{array}$ & \\
\hline
\end{tabular}

Apart from the mylonite zone at the boundary with the Simano Nappe, no other major macroscopic shear zones within the Leventina Nappe were observed at the surface within the internal parts of the Leventina Gneisses. This is intriguing as recent published observations from the construction of the new railroad tunnel (Gotthard Base Tunnel, NEAT) show that ductile shear zones at hectometric scale exist in the subsurface (Bonzanigo \& Oppizi 2006).

Heterogeneous deformation occurs at various scales in the Leventina Nappe as shown by the different shear zone patterns. The sense of shear during D2 is consistently top-to-NW in the Leventina Nappe. This is in agreement with D2 deformation in the footwall and the core of the Simano Nappe (Rütti et al. 2005). This shear sense, however, contrasts with shear senses observed in the footwall of the Adula-Cima Lunga Nappe, which are consistently top-to-SE (Table 1 and references therein). This implies that the D1 to D2 deformations in the Subpenninic Nappes, we assume to be contemporaneous, correspond to a continuous and progressive process during which a largescale change in the sense of shearing occurred, depending on the position of the nappe unit within the Alpine Nappe pile (see Meyre et al. 1998, for kinematics-time relationships for the upper units). For example, the base of the Adula Nappe exhibits top-SE shearing while the Leventina-Simano Nappes shows top-NW shearing during the same D1 and D2 nappe stacking and folding process (Table 1).

\section{Metamorphism}

\subsection{Rock Types and Mineral Chemistry}

The Leventina Gneisses have a "granitic" bulk rock composition (trondhjemitic-leucogranitic Casasopra 1939; Hiss 1975). The main minerals in the samples investigated during this study are quartz (Qtz), plagioclase (Pl) and alkali feldspar (Kfs) varying considerably in amount, and additionally, biotite (Bt) and muscovite (Ms); no paragonite was found. In addition chlorite $(\mathrm{Chl})$ or garnet $(\mathrm{Gt})$ occur with accessory phases such as apatite (Ap), zircon $(\mathrm{Zr})$, clinozoisite $(\mathrm{Clz})$, epidote (Ep), zoisite (Zs) and calcite (Cc). Hiss (1975) further mentions accessory phases such as scapolite, kyanite, staurolite and hornblende, which are found in lenses or horizons representing remnants of the country rocks of the Leventina Gneisses at the time of intrusion. Such a lens of amphibolite is observed SE of Faido (S.C. 705560/147070). It is a garnet-bearing amphibolite $(\mathrm{Hbl}+\mathrm{Pl}+\mathrm{Gt})$ with structures that are parallel to the main foliation S2. Also the rocks of the «intercalazione centrale» (e.g. road outcrops at Valbona; S.C. 706000/146600), show more semi- to metapelitic and amphibolitic mineralogical compositions. The mineral textures evolve in a general manner from more or less foliated in the core of the metagranite to strongly deformed at the boundary of the Leventina Nappe with the overlying Si- 


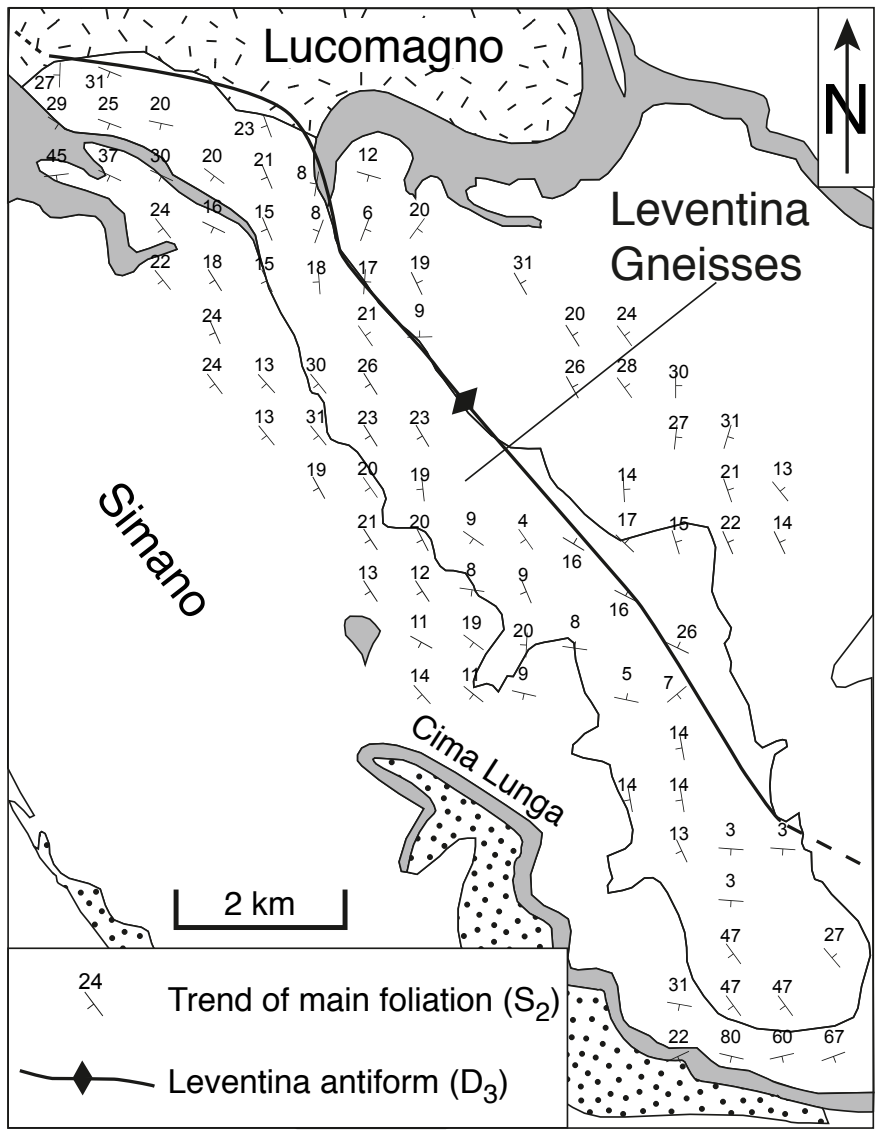

Fig. 4. Map of S2 foliations in the study area. 257 field measurements of S2 were averaged through inverse distance weighted spatial averaging with the program SpheriStat for Windows (Pangaea Scientific, Brookville, Ontario). The spacing between two points measures $1.5 \mathrm{~km}$. The D3 Leventina antiform is indicated for reference.

mano Nappe, where they show mylonitic textures (Rütti et al. 2005).

In the core of the Leventina Nappe, quartz has a large grain size ( $\mathrm{mm}$ to several $\mathrm{mm}$ ), decreasing strongly towards the mylonitic horizon of the Leventina Gneisses. In most cases, quartz shows high-energy grain boundaries, subgrains and undulose extinction.

Feldspars often form large porphyroclasts (up to several $\mathrm{cm}$ in length) in the central parts of the Leventina Gneisses. Generally they are strongly altered. Exsolution textures (exsolution blebs) were observed in almost all investigated samples. The overall grain size of feldspar depends on the structural position of the sample with respect to shear zones. Near the boundary towards the Simano Nappe, the grain size is generally small ( $\mathrm{mm}$ to several $\mathrm{mm}$ ).

Alkali Feldspar shows cross-hatched twinned microcline, and Carlsbad twins are frequent at least in the central part of the Leventina Gneisses. Flame perthites occur also quite frequently. A wide range of alkali feldspar-compositions is observed ( $\mathrm{X}_{\mathrm{Or}^{-}}$-content ranges between 0.84 and 0.97$)$. No systematic pattern of variation (e.g. core to rim) is observed; the varia- tion may be explained by cation exchange during retrograde metamorphism. In some cases the cross-hatched microcline twins are deformed.

Plagioclase often shows deformed polysynthetic twins. Myrmekite structures associated with plagioclase are frequent in most of the samples. Zoning of plagioclase is very frequent and readily observed in thin section. Plagioclase-composition also shows a range of $X_{\mathrm{An}}(0.09$ continuous to 0.21$)$, representing compositions at the albite-oligoclase miscibility gap and in the oligoclase field. Higher $\mathrm{X}_{\mathrm{An}^{-}}$-values (0.18 to 0.21) are recorded in the cores of the plagioclase grains and lower values at the rim (average around 0.16).

Micas are all recrystallized in the investigated samples. Some of the micas are deformed and show undulose extinction. Biotite growing obliquely to the main foliation (Querglimmer) is frequently observed. Biotite has a typical value for $\mathrm{X}_{\mathrm{Mg}}$ around 0.36 , but $\mathrm{X}_{\mathrm{Mg}}$ as low as 0.12 (LEV30) and as high as 0.51 (LEV35) have been measured. Chemical compositions of white micas used to deduce metamorphic pressure estimates are described in the next section (Table 2).

Generally the degree of chloritization of the samples substantially varies, ranging from almost no retrogression to nearly complete alteration of biotite. Some of the chlorite grains appear to be in equilibrium with the surrounding minerals and might have grown during the retrograde path in the chlorite stability field. $X_{\mathrm{Mg}}$ of chlorite varies less compared to the $X_{\mathrm{Mg}}$ of biotite, but also shows a considerable range from 0.34 to 0.49 (average $\mathrm{X}_{\mathrm{Mg}}$ is about 0.45 ).

Sample LEV30 additionally contains garnet grains with a skeletal or atoll habit and closely associated with quartz and feldspar. This garnet is very rich in $\mathrm{Mn}$ with $\mathrm{X}_{\mathrm{sps}} 0.25, \mathrm{X}_{\mathrm{alm}} 0.67$, $\mathrm{X}_{\mathrm{pyp}} 0.02$ and $\mathrm{X}_{\mathrm{grs}} 0.06$.

\subsection{P-T Evolution}

In order to decipher the P-T evolution of the Leventina Nappe, six samples collected along the structural NW-SE trend of the Leventina Gneisses (Fig. 6) have been studied in detail. The main objectives were to see whether the Leventina Gneisses show any change in deduced pressure of equilibration from north to south and to determine a quantitative P-T path for the unit. Equilibration temperatures in orthogneisses were estimated using observations from mineral textures. Equilibration pressures in orthogneisses were derived through the Si-content of white mica assuming equilibrium with $\mathrm{Kfs}, \mathrm{Pl}$, Qtz and Bt, using the calibrations of Velde (1965) and Massonne \& Schreyer (1987), and the calculated grid of Simpson et al. (2000).

\section{Metamorphic Temperature Estimates}

An independent estimate of the temperature of metamorphic equilibration is needed in order to apply the phengite-geobarometer to metagranitic rocks, because of its significant temperature dependence. An estimate of the temperature was derived by studying the microtextures of metagranitoids. 


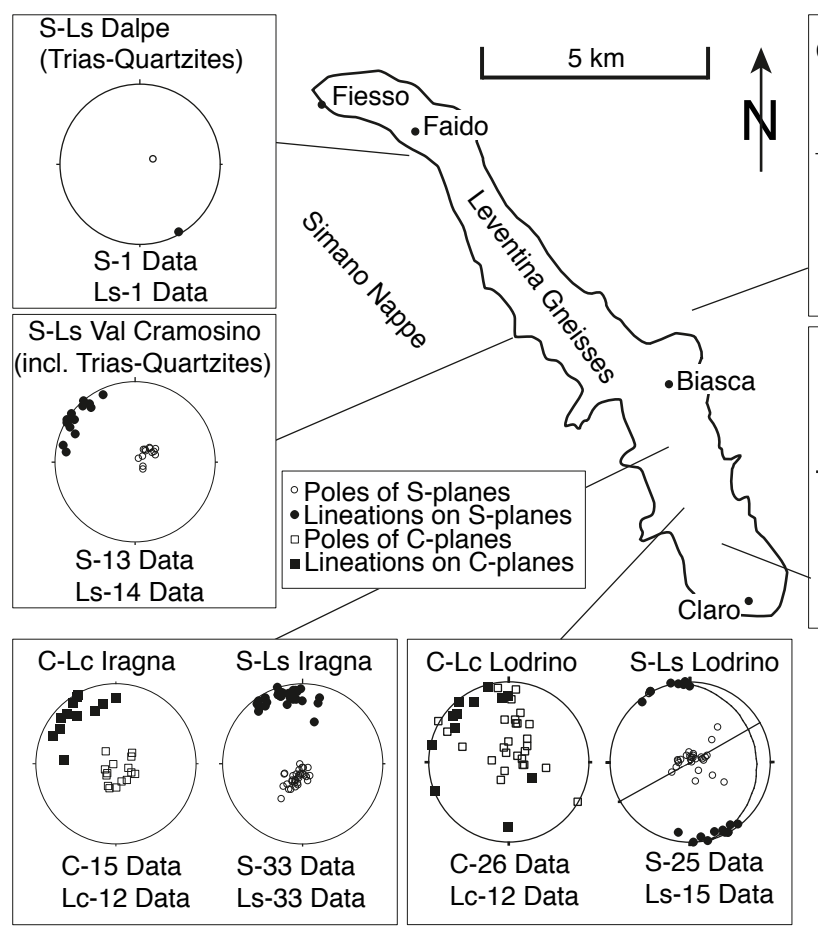

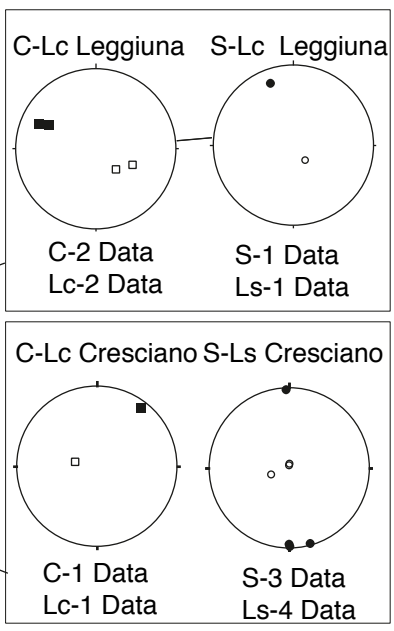

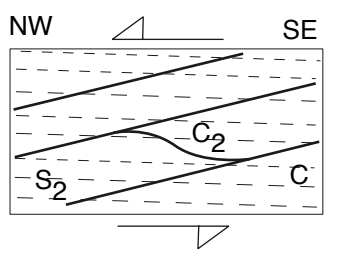

Fig. 5. Map showing stereoplots (lower hemisphere, equal area) of foliation planes (s) and lineations (L) and the associated shear bands (c) planes; Lc lineation on c planes) of selected quarries in Valle Leventina. The sketch to the right shows the field relations of the shear bands in these locations (shear sense: top-to-NW)
Minerals of all the Leventina Gneisses samples are completely recrystallized. In the core of the unit, large porphyroclasts of alkali feldspar recrystallized into alkali feldspar and plagioclase. Carlsbad twins with irregular twin faces are also frequent. The polysynthetic twins of plagioclase are usually deformed and irregularly shaped. A large number of plagioclase grains are irregularly zoned. Subgrain rotation and grain boundary migration are the processes associated with dynamic recrystallization of feldspars in the Leventina Gneisses. These processes are believed to indicate that the deformation probably took place at temperatures around or greater than $550{ }^{\circ} \mathrm{C}$ (e.g. Olsen \& Kohlstedt 1985; Pryer 1993).

Myrmekites, bulbous symplectitic intergrowth of vermicular quartz in plagioclase, are quite frequent in the Leventina Gneisses. Myrmekites are common in high-grade metamorphic and igneous rocks. Their presence in metagranitic rocks indicates equilibration temperatures of at least $550{ }^{\circ} \mathrm{C}$ (Simpson 1985; Simpson \& Wintsch 1989; Pryer 1993). Myrmekites are normally associated with plagioclase in Leventina Gneisses and two types can be distinguished: (a) Myrmekites, which are characterized by bulbous outlines and (b) myrmekite-structures present at the rims of plagioclase grains exposed to the principal strain axis Z, as described in Simpson (1985) and Simpson \& Wintsch (1989). All myrmekites are thus observed along the main foliation, regardless of the type of myrmekite (Fig. 3e). The temperature of $550{ }^{\circ} \mathrm{C}$ is therefore considered as a minimum estimate for the metamorphism of the Leventina Gneisses during D2. Based on the shape and the location of the myrmekites within the section, the processes leading to the formation of these structures is a combination of replacement of plagioclase to albite and quartz and the accommodation of deformation in the rocks (Simpson \& Wintsch 1989).

Engi et al. (1995) calculated metamorphic temperatures for the eastern part of the Lepontine zone of the Central Alps by using the multi-equilibria method of Berman (1991) and analysing metamorphic assemblages in metapelites equilibrated during the main thermal peak (syn- to post-D2). In the northern Leventina Valley the calculated temperatures range between 550 and $575{ }^{\circ} \mathrm{C}$, in the southern part of the valley (south of Biasca) temperatures of $650^{\circ} \mathrm{C}$ and higher are obtained.

\section{Metamorphic Pressure Estimates}

The main constituents of metagranitoids, alkali feldspar, plagioclase, quartz, biotite and white mica are stable over a wide range of pressure and temperature conditions and show only little variation with changing P-T conditions. Nevertheless, it is possible to closely define the metamorphic conditions in terms of continuous reactions involving changes in composition of coexisting mineral phases along both the Tschermak $\left[\mathrm{Al}_{2}(\mathrm{Fe}, \mathrm{Mg})_{-1} \mathrm{Si}_{-1}\right]$ and $\mathrm{FeMg}_{-1}$ exchange vectors (J.B. Thompson 1979). Numerous workers have reported that the Si-content in natural phengite increases (via the anti-Tschermak substitution $\mathrm{Si}(\mathrm{Fe}, \mathrm{Mg}) \mathrm{Al}_{-2}$ ) with increasing pressure and temperature in the model system $\mathrm{K}_{2} \mathrm{O}-\mathrm{MgO}-\mathrm{Al}_{2} \mathrm{O}_{3}-\mathrm{SiO}_{2}-\mathrm{H}_{2} \mathrm{O}$ (KMASH; Velde 1965; Massonne \& Schreyer 1987). Several petrological studies (e.g. Massonne \& Chopin 1989; Baudin et 


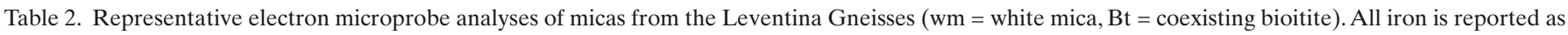

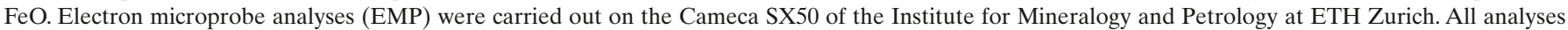

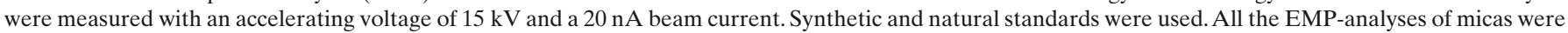

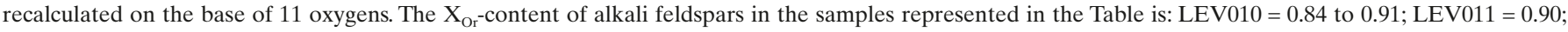
LEV029 $=0.90$ to $0.95 ;$ LEV030 $=0.85$ to $0.93 ;$ LEV035 $=0.89$ to $0.96 ;$ LEV037 $=0.90$ to 0.94 .

\begin{tabular}{|c|c|c|c|c|c|c|c|c|c|c|c|c|c|}
\hline \multicolumn{14}{|c|}{ Mineral Analyses - Leventina Gneisses (weight \%) } \\
\hline Sample Nr. & LEV010 & LEV010 & LEV011 & LEV011 & LEV029 & LEV029 & LEV030 & LEV030 & LEV035 & LEV035 & LEV037 & LEV037 & LEV037 \\
\hline Analysis Nr. & 18 & 4 & 46 & 23 & 2 & 7 & 47 & 7 & 45 & 34 & 29 & 30 & 14 \\
\hline Mineral & $\mathrm{Wm}$ & $\mathrm{Bt}$ & $\mathrm{Wm}$ & $\mathrm{Bt}$ & $\mathrm{Wm}$ & $\mathrm{Bt}$ & $\mathrm{Wm}$ & $\mathrm{Bt}$ & $\mathrm{Wm}$ & $\mathrm{Bt}$ & $\mathrm{Wm}$ & $\mathrm{Wm}$ & $\mathrm{Bt}$ \\
\hline Location & core & rim & rim & rim & core & rim & core & rim & core & rim & core & rim & rim \\
\hline $\mathrm{SiO}_{2}$ & 50,37 & 35,13 & 48,43 & 34,57 & 50,54 & 34,85 & 50,71 & 33,09 & 51,49 & 35,20 & 51,26 & 48,39 & 35,27 \\
\hline $\mathrm{TiO}_{2}$ & 0,72 & 2,62 & 0,52 & 4,46 & 0,90 & 2,13 & 0,48 & 2,92 & 0,65 & 4,03 & 0,72 & 0,89 & 2,83 \\
\hline $\mathrm{Al}_{2} \mathrm{O}_{3}$ & 31,33 & 17,58 & 34,68 & 17,09 & 28,10 & 15,80 & 29,06 & 15,32 & 28,69 & 16,58 & 31,31 & 35,21 & 18,25 \\
\hline $\mathrm{FeO}$ & 2,48 & 21,77 & 1,65 & 21,69 & 5,02 & 23,35 & 5,38 & 28,83 & 4,49 & 20,52 & 2,08 & 1,86 & 18,48 \\
\hline $\mathrm{MnO}$ & 0,02 & 0,31 & 0,00 & 0,26 & 0,02 & 0,36 & 0,07 & 0,32 & 0,05 & 0,43 & 0,04 & 0,03 & 0,27 \\
\hline $\mathrm{MgO}$ & 1,92 & 7,78 & 0,84 & 7,48 & 2,09 & 7,75 & 1,44 & 3,52 & 2,40 & 7,64 & 1,94 & 0,84 & 9,83 \\
\hline $\mathrm{CaO}$ & 0,00 & 0,05 & 0,01 & 0,00 & 0,01 & 0,03 & 0,05 & 0,05 & 0,00 & 0,07 & 0,02 & 0,01 & 0,01 \\
\hline $\mathrm{Na}_{2} \mathrm{O}$ & 0,32 & 0,10 & 0,26 & 0,13 & 0,32 & 0,10 & 0,23 & 0,06 & 0,24 & 0,15 & 0,30 & 0,46 & 0,12 \\
\hline $\mathrm{K} 2 \mathrm{O}$ & 9,77 & 9,36 & 9,67 & 9,06 & 10,17 & 9,55 & 9,75 & 8,84 & 10,11 & 9,27 & 9,58 & 9,83 & 9,35 \\
\hline Total & 96,93 & 94,70 & 96,07 & 94,74 & 97,18 & 93,92 & 97,16 & 92,94 & 98,12 & 93,89 & 97,25 & 97,52 & 94,40 \\
\hline \multicolumn{14}{|c|}{ Cations Calculated on the Basis of 11 Oxygens } \\
\hline $\mathrm{Si}$ & 3,2842 & 2,7315 & 3,1706 & 2,6879 & 3,3441 & 2,7687 & 3,3460 & 2,7362 & 3,3566 & 2,7499 & 3,3162 & 3,1327 & 2,7039 \\
\hline $\mathrm{Ti}$ & 0,0353 & 0,1531 & 0,0254 & 0,2605 & 0,0447 & 0,1275 & 0,0239 & 0,1814 & 0,0317 & 0,2367 & 0,0349 & 0,0434 & 0,1631 \\
\hline $\mathrm{Al}$ & 2,4078 & 1,6111 & 2,6758 & 1,5661 & 2,1911 & 1,4799 & 2,2597 & 1,4932 & 2,2044 & 1,5264 & 2,3871 & 2,6863 & 1,6488 \\
\hline $\mathrm{Fe}_{2}$ & 0,1351 & 1,4155 & 0,0904 & 1,4104 & 0,2778 & 1,5517 & 0,2969 & 1,9936 & 0,2451 & 1,3403 & 0,1124 & 0,1008 & 1,1850 \\
\hline $\mathrm{Mn}$ & 0,0012 & 0,0206 & 0,0000 & 0,0168 & 0,0011 & 0,0240 & 0,0042 & 0,0222 & 0,0029 & 0,0286 & 0,0020 & 0,0016 & 0,0175 \\
\hline $\mathrm{Mg}$ & 0,1866 & 0,9022 & 0,0824 & 0,8674 & 0,2062 & 0,9178 & 0,1419 & 0,4341 & 0,2333 & 0,8892 & 0,1870 & 0,0806 & 1,1236 \\
\hline $\mathrm{Ca}$ & 0,0000 & 0,0040 & 0,0010 & 0,0000 & 0,0007 & 0,0024 & 0,0033 & 0,0045 & 0,0000 & 0,0060 & 0,0014 & 0,0008 & 0,0006 \\
\hline $\mathrm{Na}$ & 0,0399 & 0,0156 & 0,0335 & 0,0203 & 0,0413 & 0,0154 & 0,0288 & 0,0089 & 0,0303 & 0,0223 & 0,0380 & 0,0579 & 0,0178 \\
\hline $\mathrm{K}$ & 0,8128 & 0,9281 & 0,8077 & 0,8986 & 0,8586 & 0,9684 & 0,8203 & 0,9325 & 0,8405 & 0,9239 & 0,7907 & 0,8116 & 0,9146 \\
\hline Total Cations & 6,9029 & 7,7817 & 6,8868 & 7,7280 & 6,9656 & 7,8558 & 6,9250 & 7,8066 & 6,9448 & 7,7233 & 6,8697 & 6,9157 & 7,7749 \\
\hline
\end{tabular}

al. 1993) have also applied the phengite geobarometer since the pioneering work of Velde (1965), e.g. Powell \& Evans (1983) and Bucher-Nurminen (1987). Unfortunately, these studies give no compositional data of the white micas and the coexisting phases.

Simpson et al. (2000) have presented diagrams of calculated isopleths for $\left[\mathrm{Al}_{2}(\mathrm{Fe}, \mathrm{Mg})_{-1} \mathrm{Si}_{-1}\right]$ and $\mathrm{FeMg}_{-1}$ in phengite relative to KMASH and KFASH end-members for the metamorphic assemblage phengite, chlorite, biotite, alkali feldspar, quartz and $\mathrm{H}_{2} \mathrm{O}$, which can be used for thermobarometry purposes. Figure 7 combines these calculated isopleths by Simpson et al. (2000) as well as the loci of the experiments carried out by Velde (1965), Massonne \& Schreyer $(1987,1989)$ to give a P-T calibration for various white mica assemblages as functions of $\left[\mathrm{Al}_{2}(\mathrm{Fe}, \mathrm{Mg})_{-1} \mathrm{Si}_{-1}\right]$ in terms of Si per formula unit (pfu).

For metamorphic equilibration temperatures around $550{ }^{\circ} \mathrm{C}$ in the north (3.36 Si (pfu) for sample LEV35) and around $650{ }^{\circ} \mathrm{C}$ in the south $(3.32 \mathrm{Si}$ (pfu) for sample LEV37) the cal- culated grid of Simpson et al. (2000; their Figure 1a), yields a range of equilibration pressures between 8 and $10 \mathrm{kbar}$ (Fig. 7). These P-T conditions correspond well with those of the Simano Nappe during D2 (Rütti et al. 2005). As the deformation along the Leventina-Simano nappe boundary occurred during D2, and hence these two rock units were in direct contact, this pressure estimate for the Leventina Gneisses is considered reasonable. The experimental fit by Massonne \& Szpurka (1997) gives higher pressures of equilibration (by up to $3 \mathrm{kbar}$ at $550{ }^{\circ} \mathrm{C}$, Fig. 7) compared to the thermodynamic calculations by Simpson et al. (2000) using the Holland \& Powell (1998) database.

The present understanding of $\mathrm{Fe}-\mathrm{Mg}$ on the white mica Si-content is ambiguous - the Holland \& Powell (1998) dataset would lower the pressure of equilibration of intermediate $\mathrm{X}_{\mathrm{Fe}}$ mica by up to $2 \mathrm{kbar}$, whereas other evidence (Massonne \& Szpurka 1997; Simpson et al. 2000) would favor increasing the pressure of equilibration with increasing $\mathrm{X}_{\mathrm{Fe}}$. We have not specifically corrected for $\mathrm{X}_{\mathrm{Fe}}$ to obtain equilibration pressures 


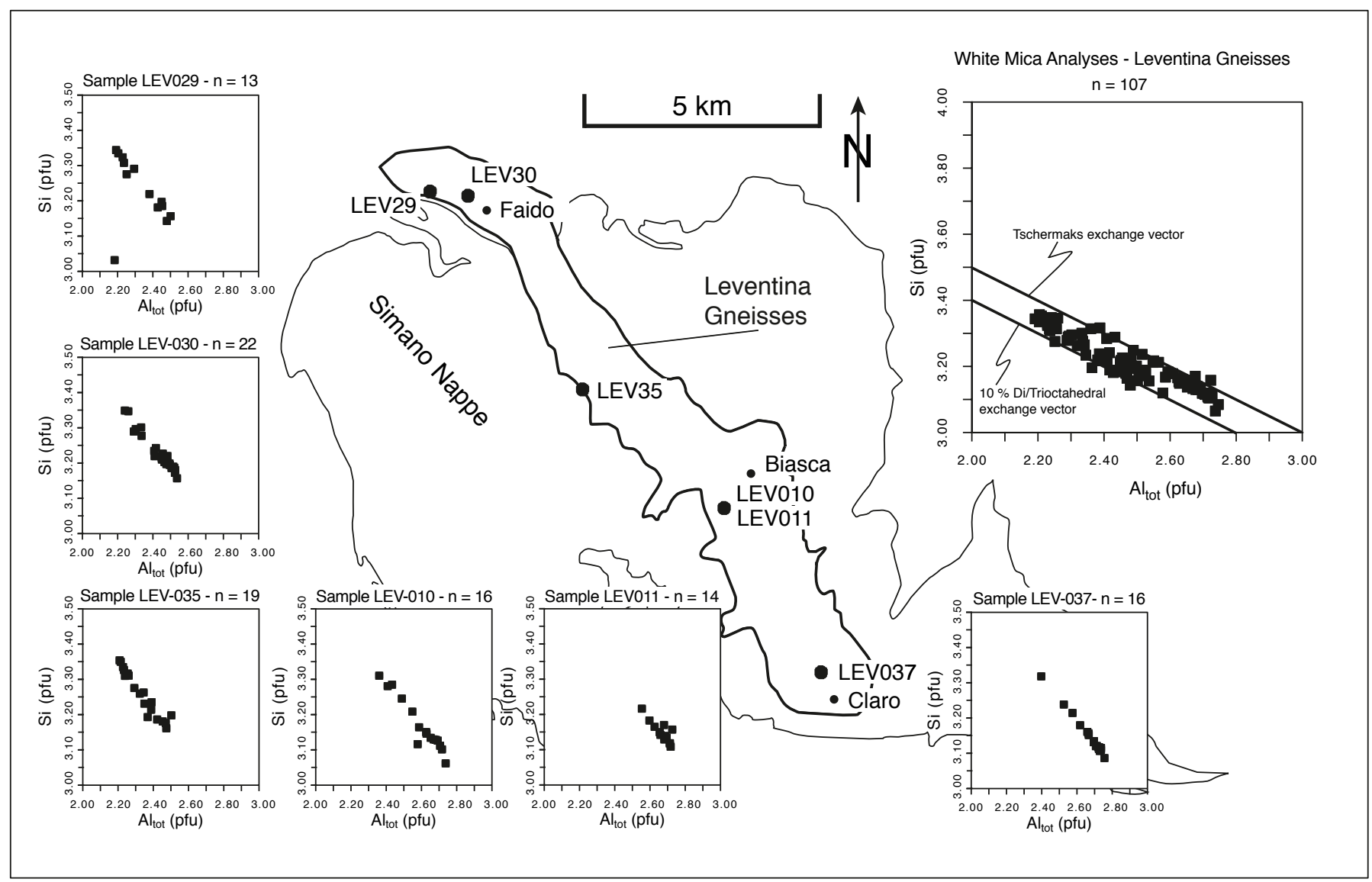

Fig. 6. Map showing the sample locations of this study. The map also shows the $\mathrm{Si}$ vs. $\mathrm{Al}_{\mathrm{tot}}$ ratio of all the measurements for white mica in each of all investigated samples (all with $\mathrm{Bt}+\mathrm{Kfs}+\mathrm{Qtz}$ ) as well as a $\mathrm{Si}$ vs. $\mathrm{Al}_{\text {tot }}$ ratio diagram with all the measurements plotted (upper right).

for the Leventina Gneisses (for equilibration temperatures between 550 and $650^{\circ} \mathrm{C}$ in Fig. 7).

The white mica compositions were also examined to determine whether differences in relative metamorphic pressure were recorded by white micas oriented in the main foliation along a profile through the Leventina Gneisses, all with the common mineral assemblage. The samples LEV29, LEV30 and LEV35 represent outcrops from the northern and middle part of the Leventina Nappe (Fig. 6) and give a comparable maximum Si (pfu) content of 3.34 to 3.35 (Fig. 6). The samples LEV10, LEV11, LEV37 show an average Si (pfu) value (3.15 to 3.18) that is lower than the one of the first group (3.23 to 3.26, Fig. 6) and could indicate re-equilibration at higher temperature (ca. $650{ }^{\circ} \mathrm{C}$; e.g. Engi et al. 1995; Kuhn et al. 2005) during the exhumation path in the southern part of the Leventina Nappe. Based on the assumed metamorphic temperatures in this study, the central and southern samples originating from the Ticino plain between Biasca and Claro, were plotted at higher temperature in Figure 8. The resulting metamorphic pressure estimate (ca. $10 \mathrm{kbar}$ for samples of the south and ca. $8 \mathrm{kbar} v$ s. for the samples in the north) therefore appears to re- flect the position of the samples within the Leventina Gneisses. The continental subduction during the collision of the Adriatic and European plates was south-directed; therefore for the samples in the south, the deduced pressures (Fig. 8) could reflect a gentle dip of the Leventina Nappe within the crustal accretionary prism.

Lower Si-values for mica rim compositions (3.14 to 3.17 for the southern samples, 3.21 for the northern samples) allow us to obtain a metamorphic pressure estimate of $5 \mathrm{kbar}$ for all the investigated samples during the exhumation path. This part of the "retrograde" path (Fig. 8) is correlated with the Tertiary exhumation of the Lepontine Nappes and could be related to D2 and D3 deformations in the Simano Nappe.

\section{Tectonic Evolution}

In the eastern Lepontine area, deduced metamorphic peak pressures are higher in the higher Subpenninic and Penninic units compared to those inferred for the lowermost Subpenninic unit (e.g. the Leventina Nappe) located in the center of the Lepontine Gneiss Region (see review in Berger et al. 2005 


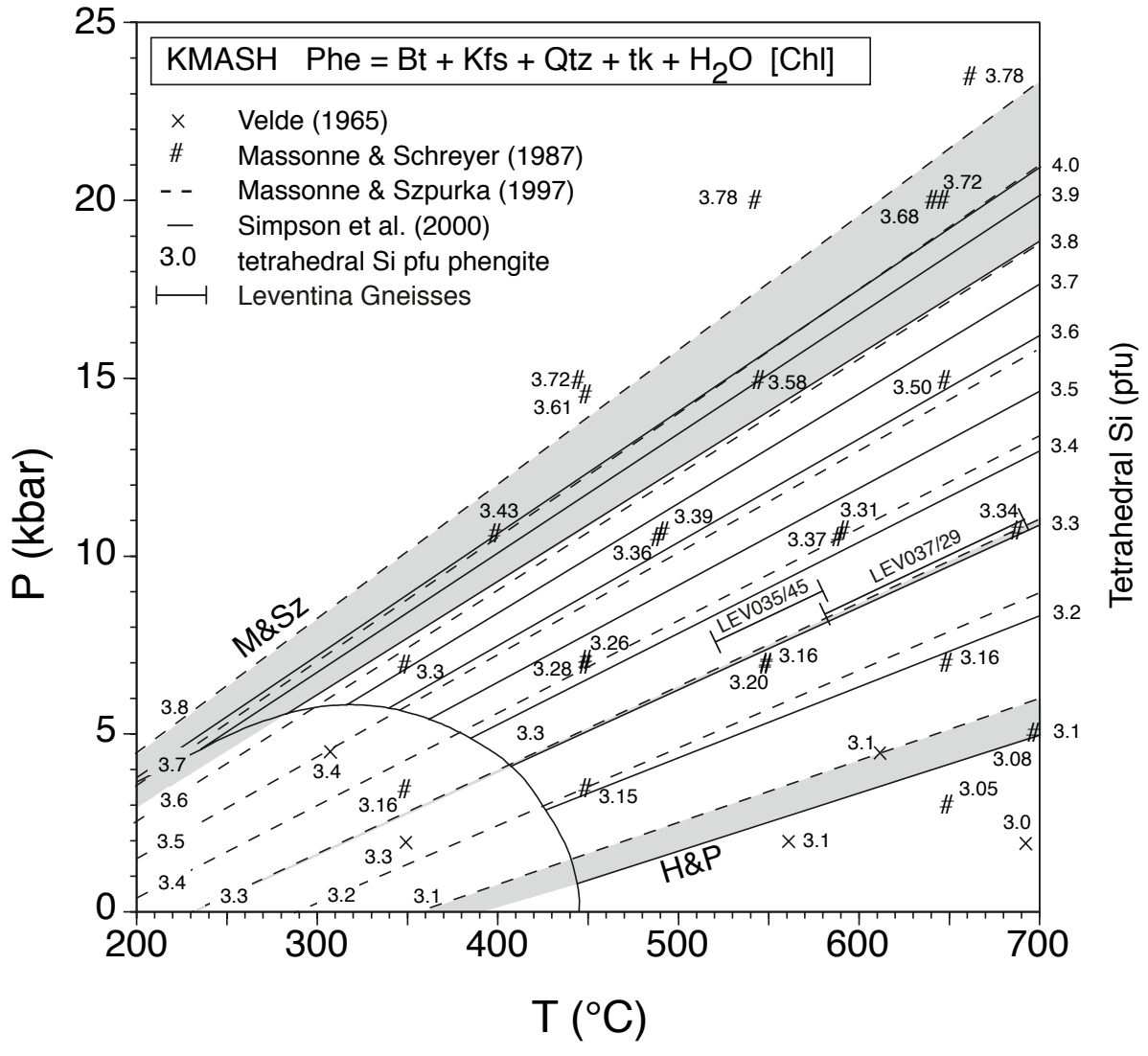

Fig. 7. P-T projection (Simpson et al.2000) showing the results of calculations (solid lines and numbers on the right side of the diagram) using the thermodynamic database of Holland \& Powell, (1998, H\&P); isopleths calculated by Massonne \& Szpurka, 1997 (M\& Sz, dashed lines); and experimental data (hash symbols: Massonne \& Schreyer, 1987; crosses: Velde, 1965) for the KMASH chlorite-absent assemblage phengite + biotite + alkali feldspar + quartz. The shaded regions in the $\mathrm{P}-\mathrm{T}$ projection indicate the difference between Simpson et al. (2000, with H\&P database) and $\mathrm{M} \&$ Sz calculations for 10,30 and $80 \%$ celadonite. and references therein). This has been explained by a subduction-related regime (Jamieson \& Beaumont 1989; Beaumont et al. 1996; Schmid et al. 1996). In such a model the Leventina Nappe stays longer in front of the rest of the Subpenninic and Penninic Nappes during progressive entrainment into the Tertiary subduction zone. Subsequently the Leventina Nappe was thrust by units that came from deeper levels in the subduction zone and that were exhumed during Tertiary collision, thus creating the present-day Alpine stack.

Figure $9(\mathrm{a}-\mathrm{d})$ illustrates the major stages of the Alpine evolution of the Leventina Nappe. The restored initial geometry of the basement of the thinned European margin before the closure of the Valais Ocean (before some $45 \mathrm{Ma}$ ) is shown in Figure 9a. After $45 \mathrm{Ma}$ underthrusting of the European Margin initiated due to the closure of the Valais Ocean. This phase generates D1 structures, nappe formation and stacking. The Adula Nappe (southernmost European Margin) is underthrusted and will later re-ascend in the accretionary prism through extrusion. At this point, the Briançonnais Tambo and Suretta Nappes have already reached their maximum burial depth (pressure peak at ca. 10 to $13 \mathrm{kbar}$ equivalent to 35 to $42 \mathrm{~km}$; Marquer et al. 1994, Nussbaum et al. 1998, Challandes et al. 2003). The Subpenninic Adula, Simano and Leventina Nappes, corresponding to the thinned European margin, are progressively individualized and stacked from 40 to 35 Ma (Stampfli et al. 1998; Meyre et al. 1998; Engi et al. 2001; Berger et al. 2005). Around 35 Ma the metamorphic pressure peak, corresponding to the deformation phase D2 in both Simano and Leventina Nappes, is attained in the depth range of 30 to $35 \mathrm{~km}$. Subpenninic and Penninic units are juxtaposed and afterwards followed together a common P-T path (Fig. 9c). The upper part of the accretionary prism thins by normal fault movements directed to the E-SE (Stampfli et al. 1998; Challandes et al. 2003). However, in the lower part of the pile there is coeval NW-directed thrusting. As a result the kinematics vary across the nappe pile: decompression at the top of the nappe pile is associated with shearing towards SE (top-to-SE), whereas stacking at the lower part of the nappe pile yields top-to-NW sense of shear (around $35 \mathrm{Ma}$ during the metamorphic pressure peak). From $30 \mathrm{Ma}$ onwards, the Lepontine Gneiss region followed a Barrovian-type P-T path. During the D3 deformation phase the nappe pile is folded into large-scale open folds (wavelength 8 to $10 \mathrm{~km}$ ) without any further internal thrusting. The underthrusting of the thick European margin (Aar and Gotthard Massifs) from the north and the Adriatic plate from the south only causes the frontal- and the southernmost parts of the Penninic nappes to be backthrusted and backfolded along the Insubric Line and south of the Gotthard Massif during late Oligocene and early Miocene, respectively (Berger et al. 2005; D4, Fig. 2). The formation of the steeply dipping Northern Steep belt occurred at around $20 \mathrm{Ma}$ in response to the underthrusting of the ex- 


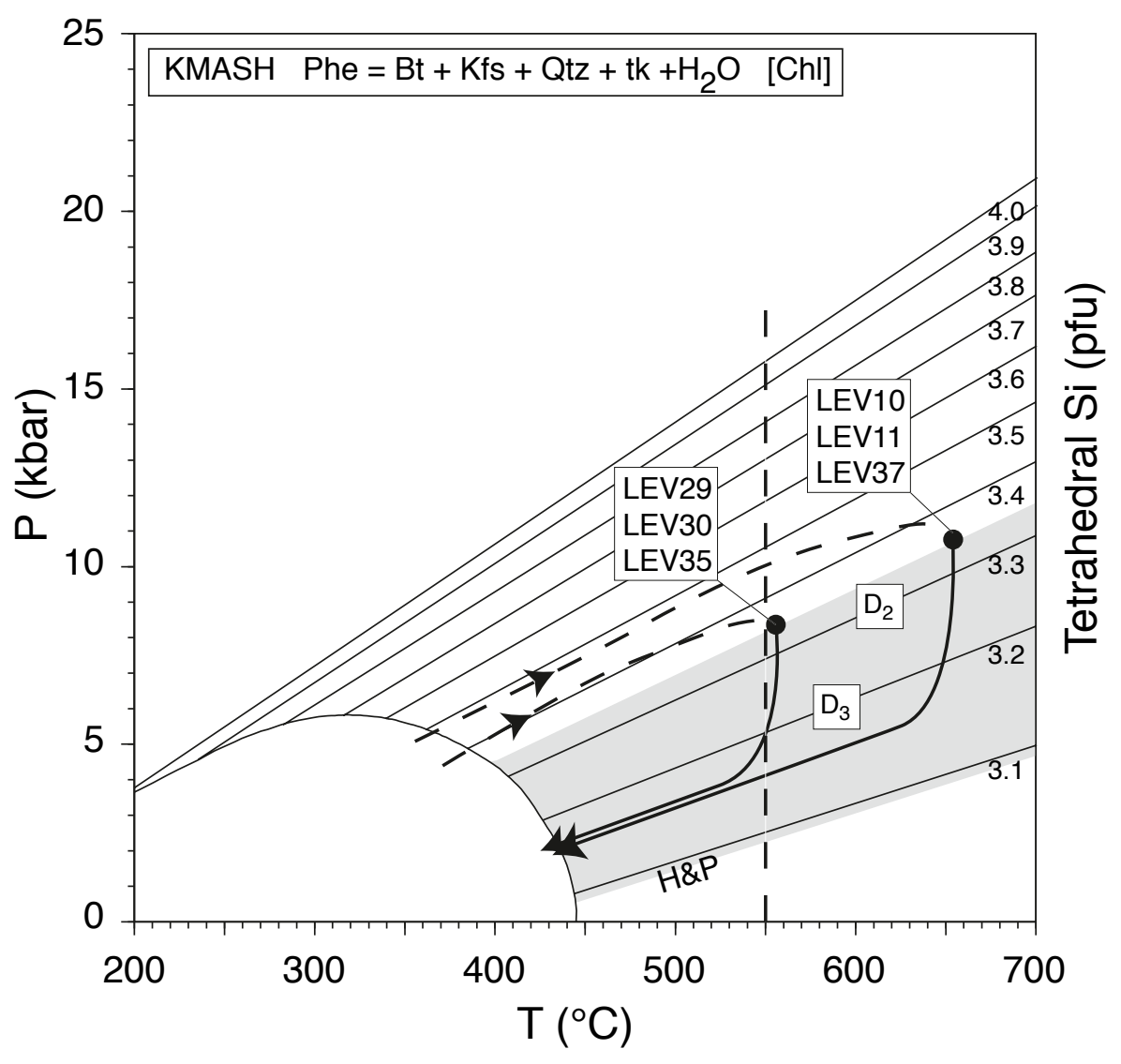

Fig. 8. Suggested P-T paths for the Leventina Gneisses with solid line isopleths from Figure 7. On the prograde path, $\mathrm{Si}$ (pfu) values in the core of white micas up to 3.36 are reached at temperatures of circa $550{ }^{\circ} \mathrm{C}$ where myrmekite is stable. The samples LEV10, LEV11, LEV37 originate from the central and southern part of the Leventina Gneisses and are therefore plotted at higher temperature of $650^{\circ} \mathrm{C}$ according to Engi et al. (1995). On the retrograde path, the chlorite stability field is reached, because biotite in the main foliation is replaced by chlorite (e.g. in sample LEV035). ternal crystalline massifs (e.g. the Aar and Gotthard Massifs; Challandes et al. 2008).

\section{Conclusions}

The Leventina Gneisses show evidence for three phases of ductile deformation. Foliation S1 is mostly sub-parallel to the regionally dominant structural fabric, the $\mathrm{S} 2$ foliation. The composite S1-S2 foliation is penetratively developed in the hanging wall toward the Simano Nappe, whereas in the core of the Leventina Gneisses, S2 is only weakly developed. A 50 to $200 \mathrm{~m}$ wide mylonite zone, showing a top-to-NW sense of shear for D2 marks the boundary to the Simano Nappe. At the surface, no major shear zones were detected within the interior of the Leventina Nappe, but mesoscopic shear zones are reported underground from the Gotthard Base Tunnel (Bonzanigo \& Oppizi 2006). In local outcrops only small shear bands (D2, mm to $\mathrm{cm}$ wide) are commonly observed. They show a top-to-NW sense of shear throughout the unit. At the outcrop scale, deformation phase D3 only locally generated a new axial plane foliation S3. However, the large-scale effects of this phase are clearly observed with the D3 Leventina antiform.

The nappe stack indicates that the Leventina Nappe represents one of the lowermost units in the Central Alps of Switzerland. Structural data of this study and Rütti et al. (2005) show that $\mathrm{D} 2$ deformation was the same both in the Leventina Nappe and the overlying Simano Nappe. At the end of the D2 deformation phase, the superposition of these two units was as observed today, later they were folded together by the subsequent D3 deformation phase.

The metamorphic microstructures and temperature calibrations quoted in the literature for the Leventina Gneisses (e.g. Engi et al.1995) associated with the dominant foliation S2, constrain metamorphic temperatures for this deformation phase at 550 to $650^{\circ} \mathrm{C}$ for the northern and southern parts of the Leventina Nappe, respectively. Si (pfu) values of white micas oriented along the main foliation are always relatively higher in the core compared to with the rim. The higher Si (pfu) values at different temperatures indicate maximum metamorphic pressure conditions at around 8 and $10 \mathrm{kbar}$ for the north and south within the nappe, respectively. The lower $\mathrm{Si}$ (pfu) values at the rim of white micas reflect pressures of $5 \mathrm{kbar}$ reached during the exhumation path.

The inferred metamorphic P-T-path shows that the estimates for the Leventina Nappe concur with the conditions estimated for the Simano Nappe during D2 and D3 (Rütti 2003), implying a common metamorphic and deformation history during these two phases of the Alpine orogeny. They are related to the underthrusting of the thinned European margin into the crustal accretionary prism that initiated during late Eocene to early Oligocene times. 
a) Before $45 \mathrm{Ma}$

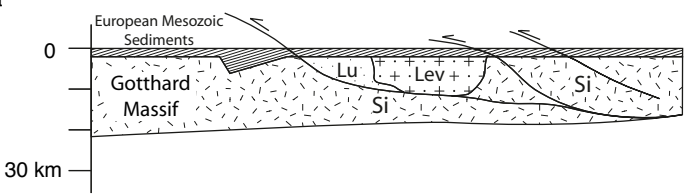

b) $45 \mathrm{Ma}$

N

c) $35 \mathrm{Ma}$

$\mathrm{N}$

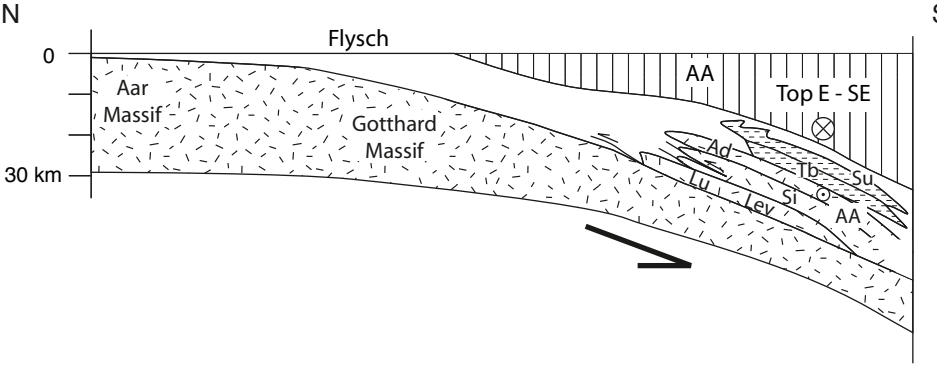

S

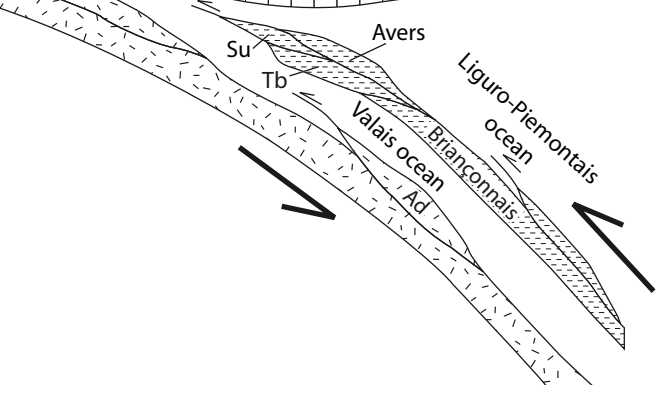

N

S

d) $20 \mathrm{Ma}$
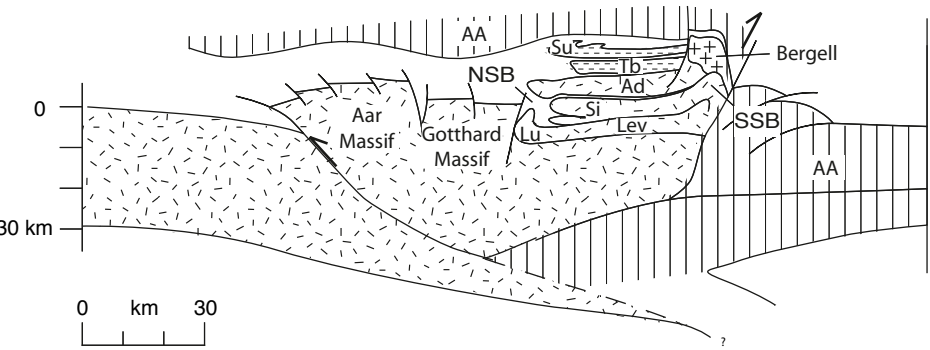

Fig. 9. Sketches tracing the major stages of the Alpine tectonic evolution of the Leventina Gneisses. Abbreviations: Lu = Lucomagno Nappe, Le $=$ Leventina Gneisses, $\mathrm{Si}=$ Simano Nappe, $\mathrm{Su}=$ Suretta Nappe, $\mathrm{Tb}=$ Tambo Nappe, $\mathrm{Ad}=$ Adula Nappe, $\mathrm{AA}$ : Austroalpine domain, NSB = Northern Steep Belt, $\mathrm{SSB}=$ South ern Steep Belt. a) presumed initial configuration of the European margin. b) Geometry during the underthrusting of the European plate. The Adula Nappe remains deep in the subduction zone, while the Suretta and Tambo Nappes are already ascending. c) Situation when the Penninic units are being stacked at 30 to $35 \mathrm{~km}$ depth. From this point onwards the Leventina Gneisses and the Simano Nappe have a common history (D2). d) Configuration of the Alpine Nappe pile during the last stage of collision, backfolding in the north and south generating the Northern und Southern Steep Belts, respectively.

\section{Acknowledgements}

This contribution is part of the doctorate thesis work of RR and funding by ETH Zürich (Grant No. 0-20738-99) is acknowledged. RR is grateful to Guy Simpson for help with white mica microscopy and mineral chemistry. The authors thank Thorsten Nagel and Djordje Grujic for the helpful reviews and Stefan Schmid for careful editing.

\section{REFERENCES}

Allègre, C.J., Albarède, F., Grünenfelder, M. \& Köppel, V. 1974: ${ }^{238} \mathrm{U} / 206 \mathrm{~Pb}-$ ${ }^{235} \mathrm{U} /{ }^{207} \mathrm{~Pb}-{ }^{232} \mathrm{Th} /{ }^{208} \mathrm{~Pb}$ Zircon geochronology in Alpine and non-Alpine environment. Contributions to Mineralogy and Petrology 43, 163194.

Baudin, T., Marquer, D. \& Persoz, F. 1993: Basement-cover relationships in the Tambo nappe (Central Alps, Switzerland): geometry, structure and kinematics. Journal of Structural Geology 15, 543-553.

Beaumont, C., Ellis, S., Hamilton, J. \& Fullsack, P. 1996: Mechanical model for subduction-collision tectonics of Alpine-type compressional orogens. Geology 24, 675-678.
Becker, H. 1993: Garnet peridotite and eclogite Sm-Nd mineral ages from the Lepontine dome (Swiss Alps): New evidence for Eocene high-pressure metamorphism in the Central Alps, Geology 21, 599-602.

Berger, A., Mercolli, I., \& Engi, M. 2005: The central Lepontine Alps: Notes accompanying the tectonic and petrographic map sheet Sopra Ceneri (1:100 000). Schweizerische Mineralogische und Petrographische Mitteilungen $85,109-146$.

Berman, R.G. 1991: Thermobarometry suing multi-equilibrium calculations: a new technique, with petrological applications. Canadian Mineralogist 29, 833-855.

Bianconi, F. 1971: Geologia e petrografia della regione del Campolungo. Beiträge zur Geologie der Schweiz NF 142, 238 pp.

Bonzanigo, L. \& Oppizzi, P. 2006: Low angle fault zones and TBM excavation in Bodio section of Gotthard Base Tunnel. In Löw S., Ed. Geologie und Geotechnik der Basistunnels am Gotthard und am Lötschberg, 155-165. vdf Hochschulverlage AG, Zürich.

Bossard, L. 1925: Der Bau der Tessinerkulmination. Eclogae Geologicae Helvetiae $19,504-521$.

Bucher-Nurminen, K. 1987: A recalibration of the chlorite-biotite-muscovite geobarometer. Contributions to Mineralogy and Petrology 96, 519-522. 
Casasopra, S.F. 1939: Studio petrografico dello Gneiss granitico Leventina (Valle Riviera e Valle Leventina, Canton Ticino). Schweizerische Mineralogische und Petrographische Mitteilungen 19, 449-708.

Challandes, N., Marquer, D. \& Villa, I.M. 2003: Dating the evolution of C-S microstructures: a combined ${ }^{40} \mathrm{Ar} /{ }^{39} \mathrm{Ar}$ step-heating and UV laserprobe analysis of the Alpine Roffna shear zone. Chemical Geology 197, 3 19.

Challandes N., Marquer D. \& Villa I. 2008: P-T-t modeling, fluid circulation, and ${ }^{39} \mathrm{Ar}-{ }^{40} \mathrm{Ar}$ and $\mathrm{Rb}-\mathrm{Sr}$ mica ages in the Aar Massif shear zones (Swiss Alps). Swiss Journal of Geosciences. DOI 10.1007/S00015-0091260-6.

Choukroune, P. \& Gapais, D. 1983: Strain pattern in the Aar granite (Central Alps): orthogneiss developed by bulk inhomogeneous flattening. Journal of Structural Geology 9, 411-418.

Engi, M., Todd, C.S. \& Schmatz, D. R. 1995: Tertiary metamorphic conditions in the eastern Lepontine Alps. Schweizerische Mineralogische und Petrographische Mitteilungen 75, 347-369.

Engi M., Berger A. \& Roselle G.T.2001: Role of the tectonic accretion channel in collisional orogeny. Geology 29,1143-1146.

Etter, U. 1992: Die Chierà-Synform. Bulletin der Vereinigung Schweizerischer Petroleum-Geologen und -Ingenieure 59, 93-99.

Gapais, D., Bale, P., Choukroune, P., Cobbold, P.R., Mahjoub, Y. \& Marquer, D. 1987: Bulk kinematics from shear zone patterns: some field examples. Journal of Structural Geology 9, 635-646.

Gebauer, D. 1996: A P-T-t path for an (ultra?) High-pressure ultramafic/mafic rock association and its felsic country rocks based on SHRIMP-dating of magmatic and metamorphic Zircon domains. Example: Alpe Arami (Central Alps). In: Earth Processes: Reading the Isotopic Code. Geophysical Monograph 95, 307-329.

Grond, R., Wahl, F. \& Pfiffner, M. 1995: Mehrphasige alpine Deformation und Metamorphose in der nördlichen Cima-Lunga-Einheit, Zentralalpen (Schweiz). Schweizerische Mineralogische und Petrographische Mitteilungen 75, 371-386.

Heitzmann, P., Frei, W., Lehner, P. \& Valasek, P. 1991: Crustal indentation in the Alps - an overview of reflection seismic profiling in Switzerland. Geodynamics 22, 161-176.

Hiss, B.M. 1975: Petrographische Untersuchungen der SBB-Sondierbohrung Biaschina (TI). Schweizerische Mineralogische und Petrographische Mitteilungen 55, 201-215.

Holland, T.J.B. \& Powell, R. 1998: An internally consistent thermodynamic data set for phases of petrological interest. Journal of Metamorphic Geology 16,309-343.

Hurford, A.J., Flisch, M. \& Jäger, E. 1989: Unravelling the thermo-tectonic evolution of the Alps: a contribution from fission track analysis and mica dating. In: Coward, M.P., Dietrich, D. \& Park, R.G. (Eds.): Alpine Tectonics. Geological Society Special Publication 45, 369-398.

Irouschek, A. 1983: Mineralogie und Petrographie von Metapeliten der Simano-Decke mit besonderer Berücksichtigung cordieritführender $\mathrm{Ge}$ steine zwischen Alpe Sponda und Biasca. Ph.D Thesis, Universität Basel, 205 pp.

Jamieson, R.A. \& Beaumont, C. 1989: Deformation and metamorphism in convergent orogens: a model for uplift and exhumation of metamorphic terrains. In Daly, J.S., Cliff, R.A. \& Yardley, B.W.D. (Eds.): Evolution of metamorphic Belts. Geological Society Special Publication 43, $117-129$.

Köppel, V., Günthert, A. \& Grünenfelder, M. 1980: Patterns of U-Pb zircon and monazite ages in polymetamorphic units of the Swiss Central Alps. Schweizerische Mineralogische und Petrographische Mitteilungen 61, 97-119.

Köppel, V. 1993: The Lepontine area, a geochronological summary. In von Raumer J.F. \& Neubauer, F., Eds. Pre-Mesozoic Geology in the Alps, 345-348. Springer-Verlag, Berlin.

Kuhn, B.K., Reusser, E., Powell, R. \& Günther, D. 2005: metamorphic evolution of calc-schists in the Central Alps, Switzerland. Schweizerische Mineralogische und Petrographische Mitteilungen 85, 175-190.

Marquer, D. 1990: Structures et déformations alpines dans les granites hercyniens du massif du Gothard (Alpes centrales suisses) Eclogae Geologicae Helvetiae 83, 77-97.
Marquer, D. 1991: Structures et cinématique des déformations alpines dans le granite de Truzzo (Nappe de Tambo: Alpes Centrales Suisses). Eclogae Geologicae Helvetiae 84, 107-123.

Marquer, D., Baudin, T., Peucat, J.-C. \& Persoz, F. 1994: Rb-Sr mica ages in the Alpine shear zones of the Truzzo granite:Timing of the Tertiary alpine P-T-deformations in the Tambo nappe (Central Alps, Switzerland). Eclogae Geologicae Helvetiae 87, 225-239.

Marquer, D. Challandes, N. \& Baudin, T. 1996: Shear zone patterns and strain distribution at the scale of a Penninic nappe: the Suretta nappe (Eastern Swiss Alps). Journal of Structural Geology 18, 753-764.

Massonne, H.J. \& Schreyer, W. 1987: Phengite geobarometry based on the limiting assemblage with K-feldspar, phlogopite, and quartz. Contributions to Mineralogy and Petrology 96, 212-224.

Massonne, H.J., Schreyer, W. 1989: Stability field of the high-pressure assemblage talc + phengite and two new phengite barometers. European Journal of Mineralogy 1,391-410.

Massonne, H.J., \& Chopin, C. 1989: P-T history of the Gran Paradiso (Western Alps) metagranites based on phengite geobarometry. In Daly. J.S., Cliff, R.A. \& Yardley, B.W.D., Eds. Evolution of Metamorphic Belts, Geological Society Special Publication 43, 545-549.

Massonne, H.J. \& Szpurka, Z. 1997: Thermodynamic properties of white micas on the basis of high pressure experiments in the systems $\mathrm{K} 2 \mathrm{O}$ $\mathrm{MgO}-\mathrm{Al} 2 \mathrm{O} 3-\mathrm{SiO} 2-\mathrm{H} 2 \mathrm{O}$ and $\mathrm{K} 2 \mathrm{O}-\mathrm{FeO}-\mathrm{Al} 2 \mathrm{O} 3-\mathrm{SiO} 2-\mathrm{H} 2 \mathrm{O}$. Lithos 41, 229-250.

Maxelon, M. \& Mancktelow, N.S. 2005: Three-dimensional geometry and tectonostratigraphy of the Pennine zone, Central Alps, Switzerland and Northern Italy. Earth Science Reviews 71, 171-227.

Merle, O., Cobbold, P.R. \& Schmid, S. 1989: Tertiary kinematics in the Lepontine dome. In Coward, M.P., Dietrich, D. \& Park, R.G. (Eds): Alpine Tectonics. Geological Society Special Publication 45,113-134.

Meyre, C., Marquer, D., Schmid, S.M. \& Ciancaleoni, L. 1998: Syn-orogenic extension along the Forcola fault: Correlation of Alpine deformations in the Tambo and Adula nappes (Eastern Penninic Alps). Eclogae Geologicae Helvetiae 91, 409-420.

Milnes, A.G. 1974: Structure of the Pennine zone (Central Alps): A new working hypothesis. Geological Society of America Bulletin 85, 1727-1732.

Milnes, A.G. 1976: Strukturelle Probleme im Bereich der Schweizer Geotraverse - das Lukmanier-Massiv. Schweizerische Mineralogische und Petrographische Mitteilungen 56, 615-618.

Nagel, T., de Capitani, C., Frey, M., Froitzheim, N., Stünitz, H. \& Schmid, S.M. 2002: Structural and metamorphic evolution during rapid exhumation in the Lepontine dome (southern Simano and Adula nappes, Central Alps, Switzerland). Eclogae Geologicae Helvetiae 95, 301-321.

Niggli, P., Preiswerk, H., Grütter, O., Bossard, L. \& Kündig, E. 1936: Geologische Beschreibung der Tessiner Alpen zwischen Maggia- und Bleniotal. Beiträge zur Geologie der Schweiz NF 71, 190 pp.

Niggli, E. \& Niggli, C.R. 1965: Karten der Verbreitung einiger Mineralien der alpidischen Metamorphose in den Schweizer Alpen (Stilpnomelan, Alkali-Amphibol, Chloritoid, Staurolith, Disthen, Sillimanit). Eclogae Geologicae Helvetiae 58, 335-368.

Nussbaum, C., Marquer, D. \& Biino, G.G. (1998) Two subduction events in a polycyclic basement: Alpine and pre-Alpine high-pressure metamorphism in the Suretta nappe, Swiss eastern Alps. Journal of Metamorphic Geology 16, 591-605.

Olsen, T.S. \& Kohlstedt, D.L. 1985: Natural deformation and recrystallization of some intermediate plagioclase feldspars. Tectonophysics 111,107-131.

Partzsch, J.H. 1998: The tectono-metamorphic evolution of the middle Adula nappe, Central Alps, Switzerland. Ph. D. Thesis, Universität Basel, Switzerland.

Passchier, C.W. \& Trouw, R.A.J. 1996: Microtectonics. Springer-Verlag, Berlin, 289 pp.

Pfiffner, M. 1999: Genese der hochdruckmetamorphen ozeanischen Abfolge der Cima Lunga Einheit (Zentralalpen). Ph. D. Thesis, ETH Zürich, $248 \mathrm{pp}$.

Powell, R. \& Evans, J.A. 1983: A new geobarometer for the assemblage biotitemuscovite-chlorite-quartz. Journal of Metamorphic Geology 1, 331-336.

Preiswerk, H., Bossard, L., Grütter, O., Niggli, P., Kündig, E. \& Ambühl, E. 1934: Geologische Karte der Tessineralpen zwischen Maggia- und Blenio- 
Tal. Geologische Spezialkarte Nr. 116, 1:50 000. Schweizerische Geologische Kommission, Bern.

Pryer, L.L.1993: Microstructures in feldspars from a major crustal thrust zone: The Grenville Front, Ontario, Canada. Journal of Structural Geology 15, 21-36.

Rütti, R. 2001: Tectono-metamorphic evolution of the Simano-Adula nappe boundary, Central Alps, Switzerland. Schweizerische Mineralogische und Petrographische Mitteilungen 81, 115-129.

Rütti, R. 2003: The tectono-metamorphic evolution of the northwestern Simano Nappe (Central Alps, Switzerland). Ph. D Thesis, ETH Zürich, 112 p.

Rütti, R., Maxelon, M. \& Mancktelow, N.S. 2005: Structure and kinematics of the northern Simano Nappe, Central Alps, Switzerland. Eclogae Geologicae Helvetiae 98, 63-81.

Schmid, S.M., Pfiffner, O.A., Froitzheim, N., Schönborn, G. \& Kissling, E. 1996: Geophysical-geological transect and tectonic evolution of the SwissItalian Alps. Tectonics 15, 1036-1064.

Schmid, S.M., Fügenschuh, B., Kissling, E. \& Schuster, R. 2004: Tectonic map and overall architecture of the Alpine orogen. Eclogae Geologicae Helvetiae $97,93-117$.

Simpson, C. 1985: Deformation of granitic rocks across the brittle-ductile transition. Journal of Structural Geology 7, 503-511.

Simpson, C. \& Wintsch, R.P. 1989: Evidence for deformation-induced K-feldspar replacement by myrmekite. Journal of Metamorphic Geology 7, 261-275.

Simpson, G.D.H., Thompson, A.B. \& Connolly, J.A.D. 2000: Phase relations, singularities and thermobarometry of metamorphic assemblages containing phengite, chlorite, biotite, $\mathrm{K}$-feldspar, quartz and H2O. Contributions to Mineralogy and Petrology 139, 555-569.

Spicher, A. 1980: Tektonische Karte der Schweiz 1:500000. Schweizerische Geologische Kommission.
Stampfli, G.M., Mosar, J., Marquer, D., Marchant, R., Baudin, T. \& Borel, G. 1998: Subduction and obduction processes in the Swiss Alps. Tectonophysics 296, 159-204.

Tektonische Karte der Schweiz 1:500000, 2005: Bundesamt für Landestopografie, Wabern.

Thompson, J.B. 1979: The Tschermak substitution and reactions in pelitic schists. In: Zharikov, V.A., Fonarev, V.I. \& Karikovskii, S.P. (Eds.): Problems in physicochemical petrology (in Russian), 149-159. Academy of Sciences, Moskow.

Thompson, P.H. 1976: Isograd pattern and pressure-temperature distribution during regional metamorphism. Contributions to Mineralogy and Petrology 57, 277-295.

Timar-Geng, Z., Grujic, D. \& Rahn, M. 2004: Deformation at the LeventinaSimano nappe boundary, Central Alps, Switzerland. Eclogae Geologicae Helvetiae 97, 265-278.

Velde, B. 1965: Experimental determination of muscovite polymorph stabilities. American Mineralogist 50, 436-449.

Villa, I. \& von Blanckenburg, F. 1991: A hornblende ${ }^{39} \mathrm{Ar}-{ }^{40} \mathrm{Ar}$ age traverse of the Bregaglia tonalite (southeast Central Alps). Schweizerische Mineralogische und Petrographische Mitteilungen 71, 73-87.

von Blanckenburg, F. 1992: Combined high precision chronometry and geochemical tracing using accessory minerals: applied to the Central-Alpine Bergell intrusion. Chemical Geology 100, 19-40.

Wenk, E. 1955: Eine Strukturkarte der Tessineralpen. Schweizerische Mineralogische und Petrographische Mitteilungen 35, 311-319.

Manuscript received 25 October, 2006

Revision accepted 21 July, 2008

Published Online first November 1, 2008

Editorial Handling: Stefan Schmid \& Stefan Bucher 